\title{
A Learning History Study of Sustainable Management in Producing an Inaugural Solar Decathlon Entry
}

Dana Shearer

Follow this and additional works at: https://researchrepository.wvu.edu/etd

\section{Recommended Citation}

Shearer, Dana, "A Learning History Study of Sustainable Management in Producing an Inaugural Solar Decathlon Entry" (2016). Graduate Theses, Dissertations, and Problem Reports. 6622.

https://researchrepository.wvu.edu/etd/6622

This Thesis is protected by copyright and/or related rights. It has been brought to you by the The Research Repository @ WVU with permission from the rights-holder(s). You are free to use this Thesis in any way that is permitted by the copyright and related rights legislation that applies to your use. For other uses you must obtain permission from the rights-holder(s) directly, unless additional rights are indicated by a Creative Commons license in the record and/ or on the work itself. This Thesis has been accepted for inclusion in WVU Graduate Theses, Dissertations, and Problem Reports collection by an authorized administrator of The Research Repository @ WVU. For more information, please contact researchrepository@mail.wvu.edu. 


\title{
A Learning History Study of Sustainable Management in Producing an Inaugural Solar Decathlon Entry
}

\author{
Dana Shearer \\ Thesis submitted to the \\ Davis College of Agriculture, Natural Resources and Design \\ at West Virginia University \\ in partial fulfillment of the requirements \\ for the degree of \\ Master of Science \\ in \\ Design and Merchandising
}

Chris Haddox, Ph.D.

Harry N. Boone, Jr., Ph.D.

Hodjat Ghadimi, Ph.D.

School of Design and Community Development

Morgantown, West Virginia

December 2015

Keywords: Solar Decathlon 2013, Green Building, Sustainability, Sustainable Management, Project Management, Off-The-Grid, Self-Sustaining Housing

(C) 2016 Dana Shearer 


\section{ABSTRACT}

A Learning History Study of Sustainable Management in Producing an Entry for the Solar Decathlon 2013.

\section{Dana Shearer}

A Learning History approach was used to study the processes and outcomes of West Virginia University's inaugural (2013) Solar Decathlon team as it planned and executed its entry to the competition. In this competition, the product must be a house that meets several standards for sustainable management of material and energy resources. This study conceives of the human resources required to produce an entry as a complementary valuable resource that also can be managed more or less sustainably. Applying principles of sustainable management to evaluate the team's process and the transmission of knowledge to future teams, analysis of the experiences and perspectives of five disciplinary team leaders point to changes that could produce a more sustainably managed competition process for future teams. 


\section{ACKNOWLEDGMENTS}

Valerie Edwards-Robeson -- For tireless and patient guidance, support, advisement, and mentorship. Very sincere gratitude, I can't thank you enough for your help. 


\section{TABLE OF CONTENTS}

ABSTRACT

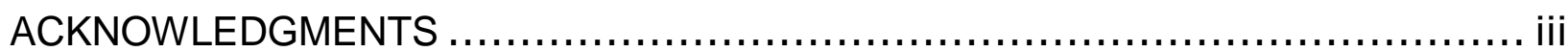

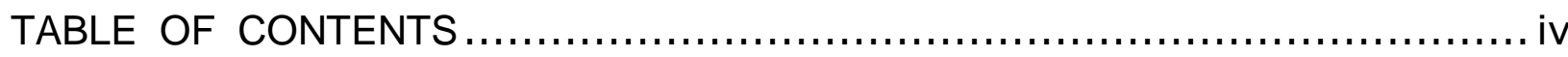

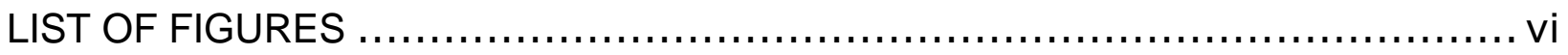

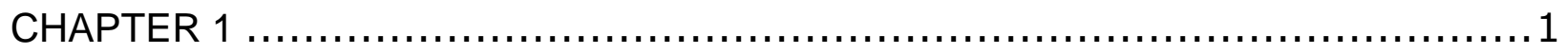

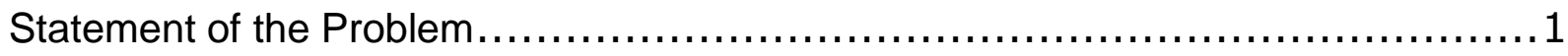

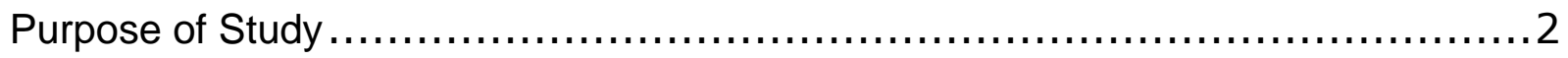

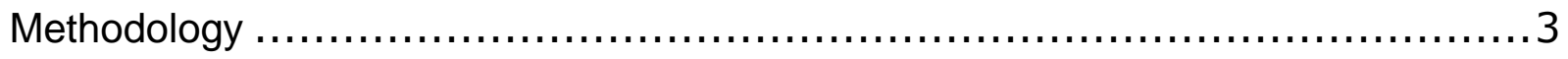

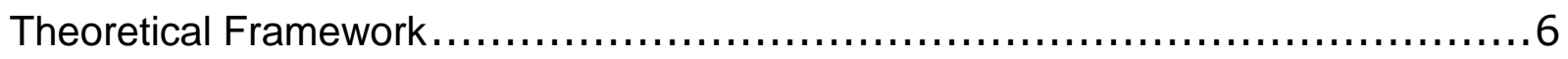

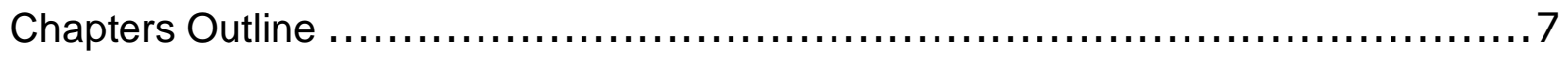

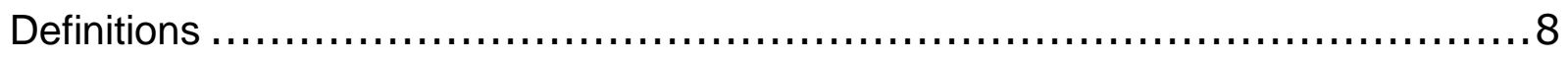

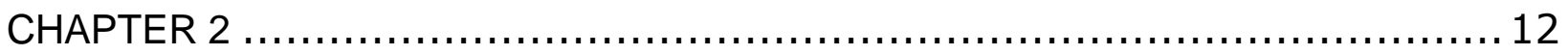

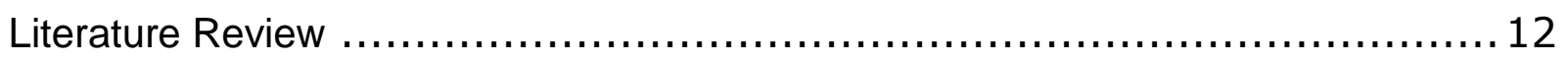

Positive Effects of Competition ............................................... 24

From Local and Small, to Global and Large .................................... 24

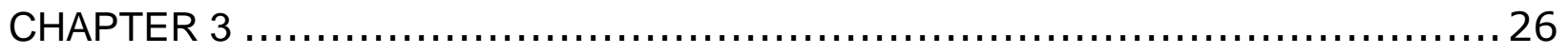

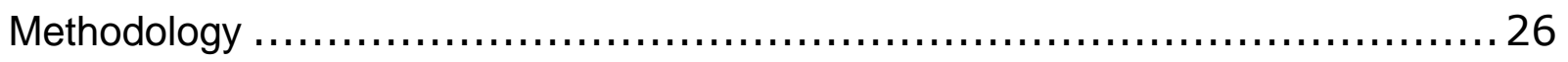

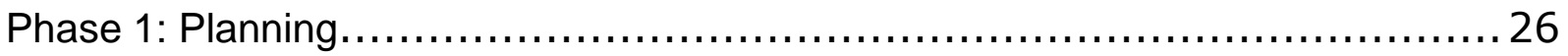




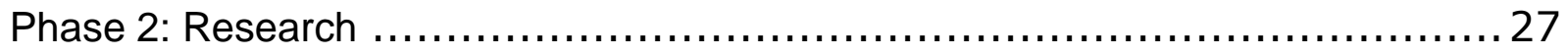

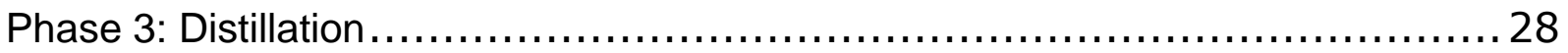

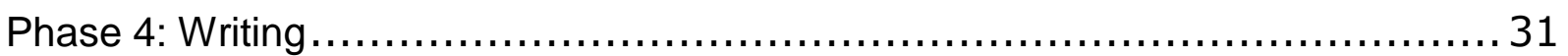

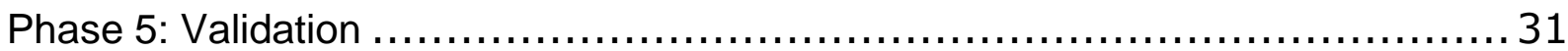

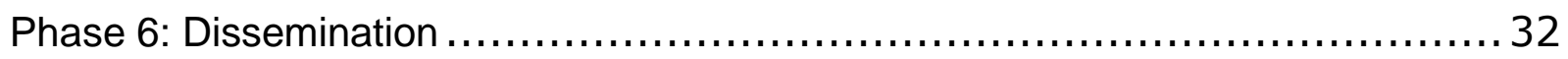

Phase 7: Publication/Outreach............................................... 32

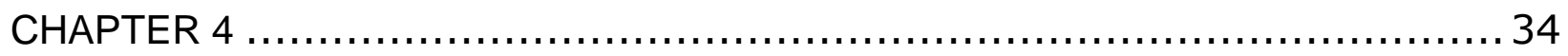

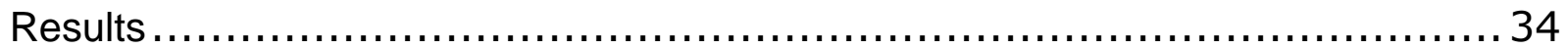

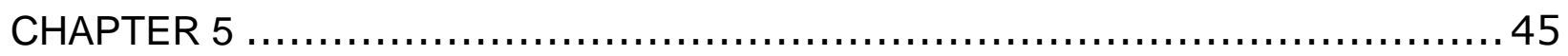

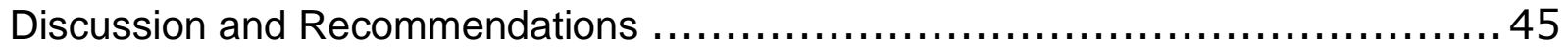

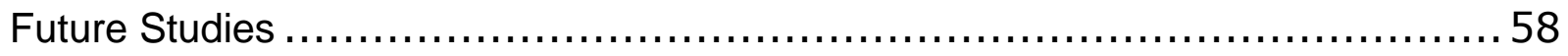

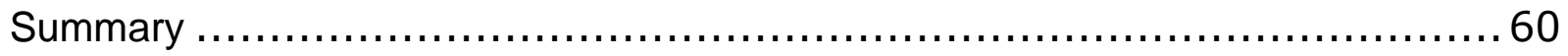

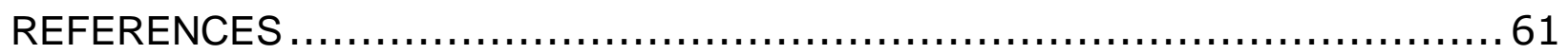

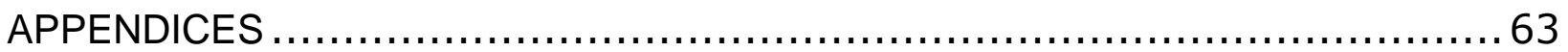




\section{LIST OF FIGURES}

Figure 1. Project Management Book of Knowledge: Planning Diagram...............23

Figure 2. Solar Decathlon 2013 Event Calendar......................................29

Figure 3. Anatomy of a Learning History Project.......................................39

Figure 4. Dana Shearer Thesis Questionnaire Cover Letter..........................69

Figure 5. Solar Decathlon 2013 Competition Deliverables.............................78

Figure 6. Project Management Institution Interactions …...........................79

Figure 7. Leadership in Energy \& Environmental Design Scorecard ...................82 


\section{CHAPTER 1}

\section{Introduction}

My professional career goal is to make an overall impact toward reducing pollution and reducing waste of energy and resources and to do this on as large a scale as possible. Humans have made Earth sick by wasting and polluting. We (humans) need to help so that it, like an organism, can heal. To put it in another perspective, since we received the world from our parents and are giving the world to our children, we should leave it as good if not better than we received it-we don't want to pass down a junky family heirloom. This study is a step toward that goal. It is a narrative and an analysis of the West Virginia University student team's entry in the 2013 Solar Decathlon. The study focuses on the perspectives of five disciplinary team leads (design studies, electrical engineering, software engineering, mechanical engineering, and landscape architecture) that were directly involved with the majority of the processes key to the project's success. The focus is to provide this study as a resource for improving future Solar Decathlon competition entries.

\section{Statement of the Problem}

Among higher education institutions, leadership skill development is an often-cited goal of curricular and co-curricular programming. Opportunities to develop leadership skills range widely, and span continua such as collaborative to competitive, local to global, discipline-specific to transdisciplinary, team to adaptive network structures, one-time events to predictively cycled processes, and others. It is difficult to confirm how leadership experiences affect students' knowledge or skill mastery, and students themselves typically lack the research skills necessary to plan and conduct learning outcomes research. Finally, positional leadership roles tend to be filled by students nearing graduation, which for most will signal the end of their association with the college or university and either the end of the learning/leadership effort or a transition to new leadership, typically from within the same institution. In combination, these factors interact to diminish the likelihood that organizational transfer of knowledge will occur. 
I believe that student engagement activities should and can lead to learning, and that learning should be documented where possible. An organization's human capital, including knowledge created through activity and reflection, are expensive and valuable resources. I apply sustainability values to reflect on the apparent waste of human capital that is evident in lost opportunities for organizational transfer of knowledge, and propose that the Learning History approach can be built into curricular and co-curricular student leadership processes with little cost and good value.

\section{Purpose of Study}

My intent is to supplement the body of existing research by providing a Learning History to discover and illustrate the attributes of two models embedded within the Solar Decathlon 2013 competition team process, in hopes of repeating the successful aspects of the competition and avoiding the unsuccessful aspects. The goal of the study is to give readers tools so that they are able to improve upon the attempt detailed in this study - to identify and transfer organizational knowledge. Specifically, the goal is to attempt a more effective application of the Project Management model, and of sustainable design values, for future Solar Decathlon competition teams. Sustainability, in this case, refers to a more "green" project - a project where the process and the final product are achieved with the minimum resources required for maximum quality, with as little waste as possible. Furthermore, assuming that the future Decathlon teams will have essentially the same resources at their disposal, the goal is to anticipate how they can better utilize what will be available to them, and also to identify and invest more energy into developing resources that will help future teams to be fully prepared for their competition. The study addresses these general questions:

- In what ways was the Solar Decathlon 2013 competition team experience consistent or inconsistent with good practice in terms of Project Management?

- Could a Learning History approach have value (produce transfer of organizational knowledge) if built into future Solar Decathlon team processes? 
This study may help West Virginia University Solar Decathlon competition team participants avoid mistakes, make educated decisions, and increase the standard of practice associated with the competition, from the perspectives of project management and sustainable design.

\section{Methodology}

The methodology for this study is a Learning History. A narrative approach typically used in social sciences, the Learning History format incorporates the experiences of the researcher and other participants in the principal event or process to be studied, so that the study can be a resource for future iterations of the same or similar events. A strength of a Learning History methodology is that it captures multiple perceptions of central events, creating more nuanced and complete understanding of the "story" the group has experienced together. The researcher's participation role allows for the collection of the data needed for later analysis.

Key assumptions are that each participant's perspective or experience of the story has value; that together these different angles give a holistic view of the organization that is more accurate and insightful than could be achieved within the view of a single narrator; that participant thoughts, emotions, and attributions of meaning will remain a private, internal, invisible, and untapped resource unless means are provided to articulate and share that resource.

Kolb and others have repeatedly confirmed that learning from experience is an essentially interior, private process, and that the value of the process can be enhanced by opportunities to reflect upon and use language to name, or identify, both the experience and the meanings or interpretations one comes to associate with the experience. Learning History studies capture the strength of the collaboratively built story and its organizational value through the use of qualitative measures: open-ended questionnaire items, interviews, and the use of primary sources generated in the group's process- for example, meeting notes, correspondence, external reports, financial records, etc. - collected from a purposively selected sample of people and 
artifacts. When the Learning History captures feedback about event intricacies, knowledge generated allows for real world applicability.

I assumed an uncompensated positional leadership role of Project Manager with the West Virginia University Solar Decathlon 2013 competition team in August, 2011, around 8 months after the team's proposal had been submitted for review among several hundred other proposals to the Department of Energy. Prior to and throughout the project, I was enrolled as a graduate student in the university's School of Design and Community Development developing an understanding of sustainable management and project management models, which shaped the perspective I brought to my experience as Project Manager and Vice President of our student union group.

The opportunity presented by the United States Department of Energy (DoE) bi-annual Solar Decathlon competition was relatively new on the landscape of student opportunities to contribute to sustainable management knowledge. At the university level, this was WVU's first competition team. The recency of this opportunity meant there was almost no literature to work from - either about the Solar Decathlon or an institutional history with the event. A graduate advisor encouraged me to consider the Learning History methodology as a resource to capture what promised to be a unique process. Following approval of the study by the West Virginia University Institutional Review Board, data was collected from key informants by means of open-ended questionnaire items and by the analysis of primary artifacts related to the group's processes during the competition.

A purposive sampling strategy was utilized to identify sources (key informants and artifacts) with essential value in terms of the three study questions. These three questions are discussed in greater detail in Chapter 3.

Key informant selection criterion was depth and breadth of relative expertise within the WVU Solar Decathlon 2013 team. The key informant sampling frame was made up of a census of every identifiable participant who acted as a member of the decision-making team through the active competition phase through submission of the final project report to the DoE. The final list of key informants was comprised of four individuals who 
occupied formally titled positions in the project - Project Manager, Engineering Lead, Design Lead, Electrical Lead, Landscape Architect, and Mechanical Lead.

The artifact frame included all of the Project Manager's project notes and calendar. Also included was: all team meeting notes, correspondence, external proposals and reports, financial records, competition checklists, and guidance documents provided by the DoE.

The questionnaire completed by key informants was developed by the researcher. Following Learning History best practices, I used primary artifacts to discern Milestone Events (Appendix B) in the team's process. Questions were framed to collect reflections and memories related to these events, and to check for other perspectives about which events may have constituted milestone events. The researcher conducted a bias screen by completing the questionnaire before distributing it to key informants. The questionnaire was distributed and returned via e-mail.

Learning Histories are a tool commonly used by laypersons - that is, people engaged in learning from events and experiences, but who do not possess formal training in research design. I will first describe a Learning History as it is typically explained in face-to-face and written summaries to lay audiences. In my description of the present study, to be presented later, vocabulary and procedures typically associated with research design will show the systematic decision-making that identifies Learning History as a research tool that combines formal and informal knowledge-building processes.

A Learning History is completed by planning, completing, analyzing and reflecting on a specific event or group process, writing about it, then learning from that event to improve or inform future events. It begins by looking at the plan for an event or process, especially including statements of what the group hopes to accomplish from their study of their own work - note this is separate from the event outcome goals or products. The learning history plan becomes a layer of the event plan, and responsibility for keeping an eye on this layer is usually assigned to a specific person - the researcher.

As the event unfolds, the study layer of the plan must also progress, by preparing interview questions and/or questionnaires for collecting perspectives, creating templates 
and clear plans for taking notes or otherwise "documenting" the process and events as they happen (for example, audio recordings, video recordings, and/or photographs), setting criteria for deciding what parts of the process / event may be significant, and obtaining the material resources needed to implement the plan (for example, a blank journal or other means for the project lead / researcher to maintain daily reflections, computer and / or audio equipment for transcribing, cameras, secured server or drive or physical storage space for holding project artifacts). In the implementation phase as the event is going on the researcher's role is to keep an open and attentive mind, and try to record the process in ways that could benefit the project and the study.

The research plan extends beyond the event plan, to allow for follow-up data collection, collective analysis / interpretation of the data, and review of the learning goals. "Archiving" (usually through writing) is the next phase. Overview, expositions, narratives, and results are to be included, amongst other relevant and/or particularly unique information. The initial draft is circulated for fact-checking, editing, and approval, the process continues with comments from previous drafts until all are satisfied (which often will result in rewriting large portions of what you had started up to that point).

Finally, dissemination and discussion conclude the process. This leaves the archived material accessible to others who may benefit.

\section{Theoretical Framework}

The theoretical framework for this study is situated within green building management and sustainable design studies. Generally, green building refers to emerging and adapting buildings or retro-fitting structures or practices to reduce the carbon footprint an organization. Events that might involve green building expertise include: planning for construction or modification of a building; comparing options for a process such as transporting a product; or deciding whether and how to change an institutional practice, for example from site-based to synchronous but distant professional development. There is already a robust field of research on the broad topic of "green technology," and the field of sustainable design has been well documented. 
Though perhaps best known for its concern with being maximally efficient in producing and using natural and material resources, sustainable design professionals often find themselves working on multi-dimensional problems with interdisciplinary colleagues to achieve a synergistic solution - a solution that achieves more than one from any single professional perspective could likely contribute alone. For example, a business considering a building addition or new purchase may need to merge concerns from several stakeholders - concerns about efficient use of natural resources will intersect with its profit standards, its recognized commitment to technological innovation, its commitment to maintaining a high-quality work environment for employees, and the need for compliance with regulations from many directions. In-house or consulting professionals from sustainability management, financial management, research and development, marketing, and human resources are all powerful resources in creating the best possible outcome for the hypothetical but representative business.

Specifically, there is ample research regarding how to implement current green technology into existing homes and new home construction. However, there is a lack of scholarship on the potential of these technologies' applications to home construction process. Although the Solar Decathlon is a competition that emphasizes and requires a "green" outcome, there are no regulations on how to get to that finished product. When people are new to an experience, time is not used as efficiently as it might otherwise be and materials are not used as efficiently as they could have been. Within this Sustainable Management theoretical framework, I will bridge the gap from competition start to finished product to improve sustainability by detailing the 2013 Solar Decathlon competition, to learn from and improve upon experiences during future Solar Decathlon competitions.

\section{Chapters Outline}

Chapter Two provides context by way of a Literature Review. Chapter Three focuses on the methodology of the study. Chapter Four reports and synthesizes the data results. Chapter Five provides a discussion of the results, recommendations for future competitions, and makes suggestions for future studies of similar topics. 


\section{Definitions}

Activity - A distinct, scheduled portion of work performed during the course of a project.

Budget - The approved estimate for the project or any work breakdown structure component or any schedule activity.

Communication Methods - A systematic procedure, technique, or process used to transfer information among project stakeholders.

Constraint - A limiting factor that effects the execution of a project, program, portfolio, or process. Often incorporated for health and safety reasons.

Deliverable - Any unique and verifiable product, result, or capability to perform a service that is required to be produced to complete a process, phase, or project (see Appendix C).

Direct Analysis (Directed Content Analysis) - A form of analysis used in qualitative content analysis research that uses a theory as a guide while analyzing data.

Execute - Directing, managing, performing, and accomplishing project work; providing deliverables; and providing work performance information.

Finish Date - A point in time associated with a schedule activity's completion. Usually qualified by one of the following: actual, planned, estimated, scheduled, early, late, baseline, target, or current.

Gantt Chart - A bar chart of schedule information where activities are listed on the vertical axis, dates are shown on the horizontal axis, and activity durations are shown as horizontal bars placed according to start and finish dates. 
Green power - a subset of renewable energy composed of grid-based electricity produced from renewable energy sources.

Learning History - a type of research thesis, like a case study, that uses a narrative approach, typically used to reflect on a specific person's experience of a particular event, often used with the goal of future improvement in similar events.

LEED - Leadership in Energy and Environmental Design, a standards rating system created by the USGBC to promote the design, construction, operation, and maintenance of green buildings, homes, and neighborhoods. This system uses forms called 'scorecards' to identify sustainable aspects of the project.

Management Skills - The ability to plan, organize, direct, and control individuals, or groups of people to achieve specific goals.

Milestone - A significant point or event in a project, program, or portfolio.

PMBOK - Project Management Book of Knowledge, a project management resource created by the Project Management Institute.

Product - An artifact that is produced, is quantifiable, and can be either an end item in itself or a component item.

Project (PMBOK) - A temporary endeavor undertaken to create a unique product, service, or result.

Project Management - The application of knowledge, skills, tools, and techniques to a project activities to meet the project requirements.

Project Manager - The person assigned by the performing organization to lead the team that is responsible for achieving the project objectives. 
Project Schedule - A generated Gantt chart-type schedule model that presents activities linked with planned dates, durations, milestones, and resources.

Project Time Management - Project Time Management includes the processes required to manage the timely completion of the project.

Questionnaires and Surveys - Written sets of questions designed to quickly accumulate information from a large number of respondents.

Renewable energy - energy sources that are not depleted by use. Examples include energy from the sun, wind, and small (low-impact) hydropower, plus geothermal energy and wave and tidal systems.

Reuse - the reemployment of materials in the same or a related capacity as their original application, thus extending the lifetime of materials that would otherwise be discarded. Reuse includes the recovery and reemployment of materials recovered from existing building or construction sites; also known as salvage.

Resource - Skilled human resources (specific disciplines either individuals or teams), equipment, services, supplies, commodities, material, budgets, or funds.

Role - A defined function to be performed by a project team member, such as testing, filing, inspecting, or coding.

Rule - A principle or regulation governing conduct, action, procedure, arrangement, etc., for the duration of the project.

Solar Decathlon - a competition hosted by the U.S. Department of Energy that challenges collegiate teams to design, build, and operate solar-powered houses that are cost-effective, energy-efficient, and attractive. The winner of the 
competition is the team that best blends affordability, consumer appeal, and design excellence with optimal energy production and maximum efficiency.

Subproject - A smaller portion of the overall project created when a project is subdivided into more manageable components or pieces.

Sustainability - a practice that focuses on minimizing and reducing the negative environmental impacts produced by humans on earth.

Sustainability studies -the interdisciplinary perspective of the sustainability concept, including: sustainable development, geography, environmental policies, ethics, ecology, landscape architecture, city and regional planning, economics, natural resources, sociology, and anthropology.

Sustainable Design - (also called environmental design, environmentally sustainable design, environmentally conscious design, etc.) the philosophy of designing physical objects, the built environment, and services to comply with the principles of social, economic, and ecological sustainability.

Sustainable Management - Managing a project, company, group of people, etc. with an all encompassing emphasis on the reduction and/or low use of social, environmental, and economic assets.

Team - The combination of team members, including team crew and decathletes, representing a single entry to the competition.

USGBC - United States Green Building Council - a membership-based non-profit organization that promotes sustainability in buildings design, construction, and operation. 


\section{CHAPTER 2}

\section{Literature Review}

This review of current literature is meant to give the reader all necessary background information needed to follow along in an informed way with the remainder of the paper. The review will give a base of information to enable the reader to form opinions about the quality of the study, findings, and conclusions.

This chapter provides information about project management and several context factors that heavily influence the study, such as Leadership in Energy and Environmental Design (LEED) project criteria, West Virginia University as a project host institution, the U.S. Department of Energy (DoE) Solar Decathlon competition, excellence markers in project management, and sustainable management. With this foundation, the reader will be able to continue to the chapters describing study procedures and results.

For the purpose of this study, there are three main categories to Project Management: Project Management as a context-specific process, typical phases of Project Management, and identified skill set requirements for Project Management.

\section{Fundamentals of Project Management}

Project Management is a Context-Specific Process. Projects are managed in the context of Organizational Strategic Objectives. Articulated organizational objectives are the basis for how Programs are developed, changed, or eliminated within an organization. Singly or in collaboration, one way programs contribute to organizational objectives is through Implementation of various Projects. Ideally, over time, programs and projects Contribute to an organization's Portfolio to demonstrate success in meeting 
its strategic objectives. The Value of a Program or Project Management in an organization's Portfolio is strongly related to Effective use of proven Project Management Techniques (see Appendix D).

Some efforts by WVU toward sustainability: various buildings have been remodeled to integrate LEED certification, and have plans to remodel several, if not all other buildings in the future; the campus has over 10 Cushman vehicles for on-campus transportation; there are programs to teach both students and community members about sustainable practices; dining services has a planning program to reduce waste; the Health and Safety department has programs to educate students on environmental protection and safety; the Information Technology department uses techniques to reduce waste; students are taught ways to purchase in sustainable ways; the transportation department is devoted to expanding alternative modes of transportation and is committed to reducing carbon along with improving air quality; the waste management department practices reduction of materials, reusing and re-purposing current materials, and recycling able materials; and the campus teaches, researches, and practices water conservation practices.

Organizational Project Management occurs at three levels: Portfolios, Programs, and Projects. Portfolios are managed to maintain focus on the strategic objectives of the organization, adapting over time. Programs unify several projects related to similar outcomes or goals. Projects are limited in scope, have narrow objectives, and have a detailed life cycle (Project Management Institute, 2013). The present study is focused on the project level. Some examples of these are below.

There is an Office of Sustainability at West Virginia University; it is administrative in nature, focused on coordinating and documenting the institution's efforts to "promote sound sustainable principles and practices through learning, teaching, research, and facilities management" (2013). Retrieved from (http://wecan.wvu.edu/strategicplan/ draft). Members of the Solar Decathlon 2013 project team were unsuccessful in establishing communication or partnership with this office. 
The Solar Decathlon competition has supplied the University opportunities for promotional material, shown examples of design and technological potential, as well as opportunities to collaborate with other organizations. This competition has also provided opportunities for students to go above and beyond school requirements, to get exposure to professionals and other organizations, to apply their knowledge in real world scenarios, and greater depth overall to their learning experience in several fields. Some actual examples of this will be included later in this chapter.

Organizational Strategic Objectives: WVU'S Office of Sustainability is working in several ways to improve their sustainability, including: Buildings and Grounds, Co-Curricular Education, Community and Civic Engagement, Curricular Education, Dining, Energy, Health and Safety, Purchasing, Recycling, Research and Innovation, Transportation, and Water. (http://wecan.wvu.edu/strategicplan/draft)

WVU's Sustainability Project Management:

\section{WVU SOLAR DECATHLON 2013 TEAM MISSION}

PEAK or Preserving Energy with Appalachian Knowledge - was designed with one vision in mind: to capture the Appalachian Spirit of West Virginia and bring it to the competition. Our home strives to create a rustic, homey living environment while incorporating contemporary living and smart automation. We plan on bringing a house to the competition unlike any it has ever seen before. Tradition and innovation are strongly conjugated in PEAK. Its unique style features elements of a rustic log cabin, without sacrificing sustainability and modernization. PEAK will pave the way for the next era of energy leaders to combine state tradition with advanced technology and cleaner fuel sources. The composition of the house brings attention to the ways Appalachia can use what nature so abundantly provides to produce housing with minimal environmental impact. (PEAK Project Summary, 2013, p. 1) 
WVU's Sustainability Program Management:

\section{WVU MISSION}

As a land-grant institution in the 21st century, West Virginia University will deliver high-quality education, excel in discovery and innovation, model a culture of diversity and inclusion, promote health and vitality, and build pathways for the exchange of knowledge and opportunity between the state, the nation, and the world. (https://about.wvu.edu/wvu-facts)

\section{WVU VISION}

By 2020, West Virginia University will attain national research prominence, thereby enhancing educational achievement, global engagement, diversity, and the vitality and well-being of the people of West Virginia. (http://strategicplan.wvu.edu/r/download/90091)

\section{WVU OFFICE OF SUSTAINABILITY MISSION}

As a land-grant institution, West Virginia University will support, advance, practice, and promote sustainability (environmental performance, economic prosperity, and social responsibility) in its pursuit of leadership and prominence in research, teaching, and service; stewardship of institutional resources and services; and relationship with the local community, state, nation, and beyond."

(http://wecan.wvu.edu/strategicplan/draft)

\section{OFFICE OF SUSTAINABILITY'S VISION}

West Virginia University will create and instill a culture of sustainability that will guide its teaching, research, and outreach mission.

(http://wecan.wvu.edu/strategicplan/draft) 


\section{WVU's Sustainability Portfolio Managment:}

In terms of using the Decathlon as an electronic portfolio tool, The Davis College of Agriculture, Natural Resources, and Design used the competition to their advantage the most, with around 250 links to articles involving the Solar Decathlon. Where the Statler College of Engineering and Mineral Resources only had around 50 links. The Office of Sustainability and Reed School of Journalism had around 25, and the University as a whole had about the same amount of links (used only when related to its strategic plan). Sadly, the College of Creative Arts (which made our flatware and interior art pieces) didn't post a single thing about the project. Some examples of these articles can be found in Appendix E.

After projects and programs are established and then portfolios are started, there is an atmosphere that sometimes develops called "Organizational Culture". (Project Management Institute, 2013, p. 20) This culture occurs when members of the organization begin actions that turn into habits that turn into practices. Some of these practices that WVU's Solar Decathlon team used are:

Shared vision, mission, values, beliefs, and expectations; regulations, policies, methods, and procedures; view of leadership, hierarchy, and authority relationships; and operating environments.

(Project Management Institute, 2013, p. 20)

The Role of a Project Manager (PM): After determining the set of tasks needed for project completion, the PM applies the five processes to further plan for complete of each task: the initiation phase, the planning phase, the executing phase, the monitoring phase, and the closing phase. More detailed:

Initiation phase - determining that the event is needed and that

project management is needed for that event

Planning phase - determining how much of each asset is needed to complete the event

Executing phase - communicating to persons involved the information 
needed to allow them to complete the tasks assigned by the necessary deadlines

Monitoring phase - maintaining communication with those involved, constantly comparing what is happening with the actions and timeline as planned, reallocating assets to adapt the timeline to realign actual with planned accomplishments

Closing - also referred to as the celebration phase; communicating the outcome of the process to all involved and any external stakeholders as necessary; distributing recognition, appreciation, etc. to sustain morale and participant engagement.

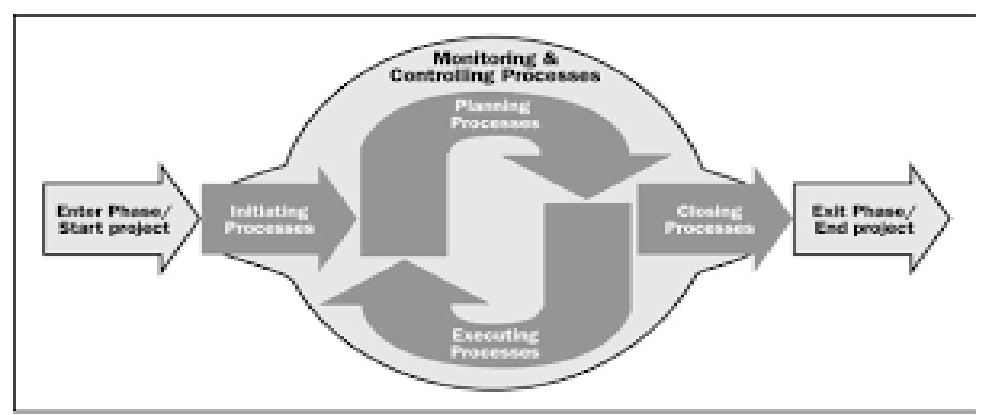

Figure 1: 2013 Project Management Institute PMBOK Guide p. 50 Figure 3.1

According to the Project Management Institute, the project manager has three complimentary categories of assets in project management, they are: economic (money), environmental (materials), and social (people). These are assets that the project manager has at their disposal in managing a project. These assets are used in concert to achieve the above phases.

The fundamentals of project management are accomplished through these five sequential, cyclical processes: initiating, planning, executing, monitoring, and closing. Each project requires that it be broken down into as many "events" or tasks, as are prudent and manageable. The Project Manager's (PM's) role is to determine the appropriate level of event-to-task breakdown so that the group can accomplish the tasks necessary in the usually predetermined amount of time. Among the assets available to complete the tasks are money, materials, and people. Asset use is determined in 
relationship to time constraints on the project. For example, a shorter time limit will require more people or person hours on a project. In the case of insufficient expertise or materials, additional money resources will be needed to compensate. If there are only few people and low funds, the project will take more time to complete.

There are other considerations for the PM to keep in mind: regularly, there will be some tasks that cannot start until other tasks are completed. Another consideration is that also, regularly, tasks will be overlapping and occurring at different times during the project (Project Management Institute, 2013).

Project Management requires identified interpersonal skills, as described by the PMBOK: "Leadership, Team building, Motivation, Communication, Influencing, Decision making, Political and cultural awareness, Negotiation, Trust building, Conflict management, and Coaching" (Project Management Institute, 2013, p. 513).

For every project-related event, the manager's role is to determine how much of each asset is needed, and also determine the importance of each asset and manage them accordingly. Usually the most challenging aspects will be economic assets and the environmental asset of time. These are typically in finite supply, leading to the need to manage the other assets so that these are conserved.

Another concept the researcher kept in mind and focused on was integrating green principles into the construction of the house itself, specifically, integrating Leadership in Energy and Environmental Design (LEED) concepts. This meant the integration of sustainable practices into the entire house construction process. One way LEED incorporates sustainable practices is by finding a prudent balance between social, environmental, and economic resources (see Appendix F).

The United States federal government defines green as "products and services that reduce health and environmental impacts compared to similar products and services 
used for the same purpose," (2014). Retrieved from https://www.green2sustainable. com/about says Steve Ashkin, president of The Ashkin Group and chairman of the Sustainability Dashboard. Sustainability, on the other hand, "can be represented with a three-legged stool having a leg for environmental, social and financial responsibility," (2010). Retrieved from (http://www.greeningdetroit.com/wp-content/uploads/2010/01/ Green-Leader-James-Newman.pdf) according to Jim Newman, owner of Newman Consulting Group. "With green, our consideration about people and staff is limited to direct exposures from products or services," (2014). Retrieved from (https://www. green2sustainable.com/about) says Ashkin. "Sustainability is a much broader term that talks about the implications of those products and services used over a much longer period of time, and considers social and financial impacts as well." (2014). Retrieved from http://www.cleanlink.com/hs/article/The-Difference-Between-Green-AndSustainability--13976\# sthash.Nb5ujJOv.dpuf

Next are some other notes to keep in mind while acting as a project manager. If necessary, a subsequent event can be created, reactivating the initiation phase, and proceeding through the cycle again. In the case of simultaneously occurring events, the PM must effectively juggle different phases of the management process at the same time, to maintain momentum for each event. There is an ultimate goal or ideal outcome for each project to be managed, but there are also secondary and tertiary goals to be set and accomplished in the meantime.

To give more information on what is needed to award a building with LEED certification, shown in Appendix F, means adopting several practices, and making sure your house has: community connectivity, transportation access, maximum open space, quality control in building materials, quantity control in building materials, minimal heat island effect on both roofs and non-roof surfaces, reduced light pollution, reduced water use, water efficient landscaping, building energy systems, energy performance, refrigerant management, on-site renewable energy, green power, ongoing measurement and verification, storage and collection of recyclables, construction waste management, material reuse, recycled content, recycled materials, rapidly renewable materials, 
certified wood, indoor air quality performance, low emitting flooring materials, thermal control, daylight use and outside views. The researcher kept all of these concepts in mind during the design, construction, and maintenance of the house that was the outcome of the WVU 2013 Solar Decathlon project.

\section{Learning History Research}

The purpose for a Learning History is to: change and improve current practices of an organization, to build upon an experience, and to avoid making mistakes that are similar to a past set of circumstances. Some other possible reasons are: to analyze an organization's shortcomings and achievements to stop and repeat them respectively, and to break tradition and adapt to current and future times.

According to Field Manual for a Learning History, there are seven general phases to the Learning History process: planning, research, distillation, writing, validation, dissemination, and finally publication/outreach (Kleiner \& Roth, 1996), discussed in detail later in this chapter.

Also, as per the Field Manual for a Learning Historian, some quality indicators of a Learning History: its use of events which people in the organization consider significant, its purpose is for an audience broader than the participants, data generated through reflective conversations, commitment to a jointly-told tale, it's use of a team of insiders and outsiders, links attributions and observable data, and use of the study as a means to a better conversation.

Above are some broader framework components of a Learning History, below is a more narrowed, focused description. As above was a wide snapshot of a Learning History, below is zoomed-in, specific look at components of a Learning History.

A Learning History methodology uses aspects of action research and organizational development (Kleiner \& Roth, 1996). As opposed to a traditional case study, Learning 
History does not use tabulated number data but explains, in detail, an event for the purpose of managing a similar event in the future.

In order to examine the merits of the Solar Decathlon, we need to employ a Learning History framework. According to Kleiner and Roth, "A key goal of Learning History work is to create...'Reflectionable knowledge' which often exists in the form of stories" (Kleiner \& Roth, 1996, p. 9). Moreover, a key method for collecting data in a Learning History is through interview or qualitative questionnaire. The Learning History is relatively new with Kleiner and Roth's Field Manual for a Learning Historian written in 1996. The beginning of the Learning History takes roots in Massachusetts Institute of Technology (MIT), and was the result of answering one main question: "How do you take the experience and understanding of a pilot team in an organizational learning effort, and make it relevant to the rest of the organization." (Kleiner \& Roth, 1996, p. 24) There are several instances that can take advantage of a Learning History: learning from a pilot project, creative imperatives, a jointly-told event, learning from a champion

or master of craft, public education and outreach, even an organization learning from its own practices to increase capability.

The focus of this Learning History is on the 2013 Solar Decathlon. The utility of a Learning History for the university in this circumstance is because this is the first year, or pilot, for WVU. Since this is the beginning of a program that WVU is producing, a Learning History has great potential.

\section{Solar Decathlon History and Research}

The Solar Decathlon is a global competition sponsored by the Department of Energy that invites scholastic institutions to submit proposals for student teams to design and build a fully functional, off-the-grid house. The Decathlon is highly advertised and is becoming more known throughout the world. From among the global application pool, 20 proposals are selected for the actual competition. WVU first became involved in the 
competition when a student visited the 2011 Solar Decathlon. Since 2013 is the first time that WVU had entered the competition, this study will attempt to provide insight for future competitions.

There is little research on the Solar Decathlon and other initiatives undertaken by novice students of this field. There is a large amount of documentation on the Solar Decathlon in its pre-emptive phases and also plenty of documentation of completed houses. There is not, however, an abundance of information of the process in-between. This may be due to the competitive nature of the Decathlon and that teams do not wish to divulge the "secrets" that each respective team has discovered.

Understandably, here has been a relatively small amount involved with and/or mentioned in past studies, since the Solar Decathlon competition as a whole only started in 2002, and is only every other year. Additionally, there is even less research available in Sustainable Management and Project Management within this context. During the two week on-site construction phase, the goal of these 20 teams is to build an off-the-grid, self-sustaining house. Specifically, the Solar Decathlon challenges collegiate teams to design, build, and operate solar-powered houses that are costeffective, energy-efficient, and attractive. The winner of the competition is the team that best blends affordability, consumer appeal, and design excellence with optimal energy production and maximum efficiency (U.S. Department of Energy, 2013). 


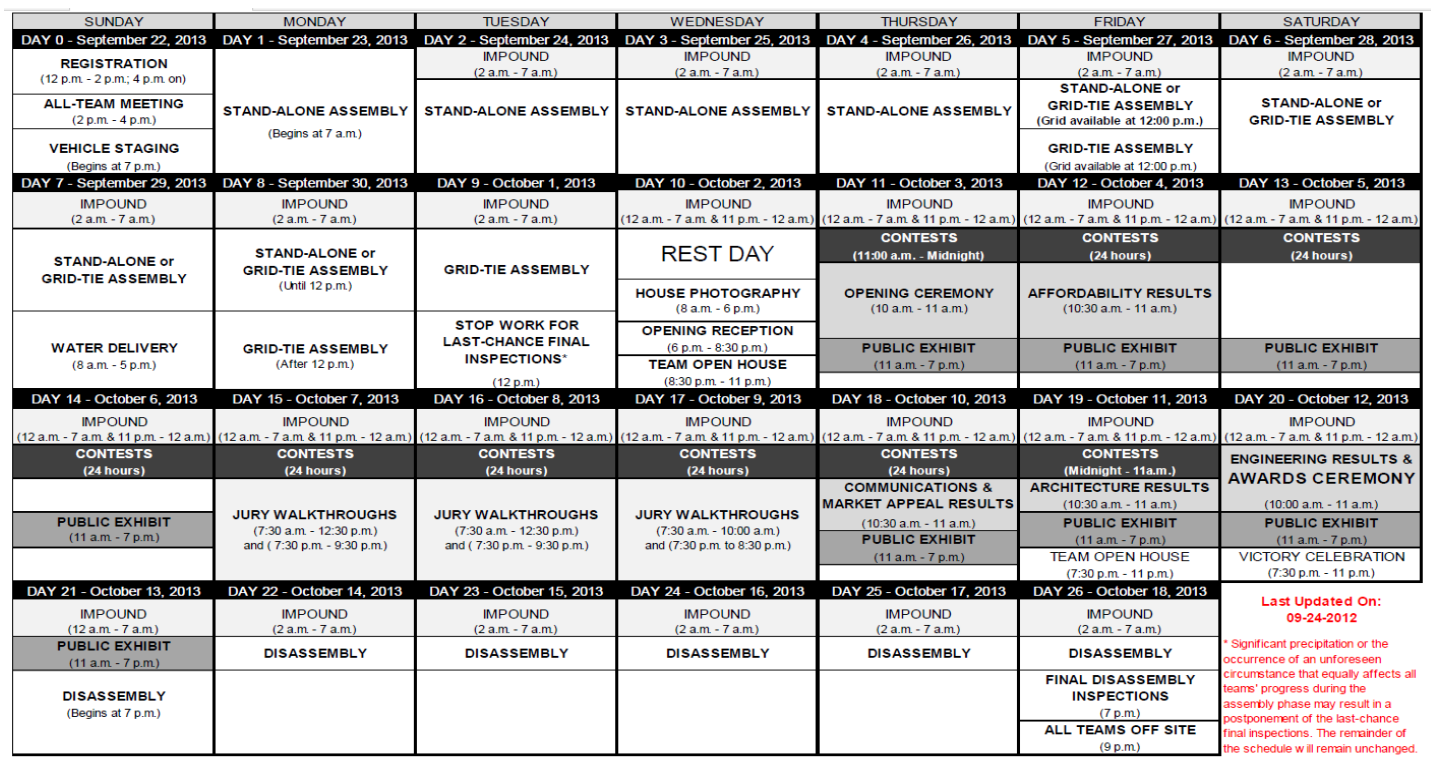

Figure 2: SD2013 Rules v1 p. 33 Appendix A; A-1: Overall Event Calendar

Since it's an international competition hosted by the Department of Energy, which is a federal agency, there were constraints that we had to abide by. Teams had to have a stand-alone power and water supply, and other constraints, as articulated by the official DOE website (U.S. Department of Energy, 2013).

One constraint specified by the 2013 Solar Decathlon committee was that the house had to be stand-alone. By that, the home had to function fully without the assistance of city power, water, and sewer (U.S. Department of Energy, 2013). Other constraints included: teams could only use commercially available technology, teams had to work within a footprint that was 78 feet wide by 60 feet deep, and the tour route had to be Americans with Disabilities Act (ADA) compliant. These constraints and more made the competition complex and required in-depth preparation. The DOE requested that the teams plan by requiring assignments to prove that the teams had been preparing for these constraints (U.S. Department of Energy, 2013). The assignments provided a scaffold process through which each team had to reach benchmarks by pre-set dates.

In a study of the 2013 Solar Decathlon by Garkhail (2014), supporting evidence showed that all of the homes that were tested were found to be efficient through Energy 
Performance Analyses. In yet another study of the 2013 Solar Decathlon, Mulepati (2013) found additional evidence of the potential of net-zero homes when they were compared to Energy Star and non-Energy Star homes. There was similar findings in a study done by Wallpe (2012) of the 2011 Solar Decathlon, where it was found that commercially available technology could be used to create affordable, net-zero homes.

\section{Positive Effects of Competition}

Hawken (1993) argues that the Solar Decathlon is an important event because the point of the event is to find creative ways-with technology of the day - to sustainably build and maintain a household through competition. Like Hawken; Nidumolu, Prahalad, and Rangaswami (2009) insists that competition (like business) drives the Solar Decathlon. Competition sprouts creativity, which supplies new ideas and ways for further growth. In this case, hopefully, competition creates innovative ways to integrate green practices into every household on a global scale. According to the author, being sustainable is not as costly as one might assume: "Sustainability isn't the burden on the bottom lines that many executives believe it to be. In fact, becoming environmentally friendly can lower your costs and increase your revenues" (Nidumolu, Prahalad \& Rangaswami 2009, p. 1). In addition to creativity, business is an integral part of the competition. Hawken supports Mulepati's theory that "business is part of the problem and it must be part of the solution. Its power is more crucial than ever if we are to organize and efficiently meet the world's needs" (Hawken, 1993, p. 17). Business is important because of its supply and demand nature, driving technology of the competition to the masses.

\section{From Local and Small, to Global and Large}

Another reason for the competition is to engage and educate the public to see the opportunities available to them to save money, save energy, and save the planet. And through this public involvement, the collegiate team's students can get a highly effective immersive opportunity to acquire the perspective necessary to teach and train others, which will greatly help their future endeavors. The competition has helped over 30,000 
students so far and has served as a model for other competitions: Solar Decathlon Europe, Solar Decathlon China, and Solar Decathlon Latin America and Caribbean, which are also biennial. Boetti and Leandro (2008) also support going global with knowledge through a study that showed the possibility of using social media for team communication and world-wide education.

In addition to a tool for global education, the Solar Decathlon also illustrates how a team of individuals can make a difference within the process of green building. Often times, people do not try because they think the problem is too big and that they cannot make a difference because they are just one person. There is a quote by Anita Roddick that she used regularly "If you think you are too small to have an impact, try going to bed with a mosquito in the room" (2001) Retrieved from https://www.goodreads.com/author/quotes/ 237031. Anita Roddick. As such, the Solar Decathlon provides an opportunity for individuals to make a difference, whether small or large, and groups of individuals to work together to accomplish a common goal.

The project was successful in the respect that the solar house was completed. Progress of the house was not completed as planned, which pushed back each sub-sequent phase of the project. This resulted in the house not being completed as planned, before the beginning of the competition. This degree of completion is what was needed to be fully prepared on or before the first day and throughout. 


\section{CHAPTER 3}

\section{Methodology}

As stated in previous chapters, the primary methodology for this thesis is a Learning History. Consistent with that methodology, the study is created to fulfill a specific need, to record past experiences, and to reflect on those experiences to produce organizational knowledge for organizational growth and stability. Aspects of the Learning History methodology are that participants of the event "need to judge the value of their past experience, if only to help their organizations move forward, and to develop their judgment and skills further" (Kleiner \& Roth, 1996, p. 1). Learning History methodology is a category of action research, and the purpose is to create an environment that encourages the creative relationship between action and reflection and uses synergy between scholarship and practice, which make useful dialogues (Bradbury \& Mainemelis, 2001). The study is meant to create and pass on knowledge of value in a specific context-this is a great use of a Learning History.

\section{Phase 1: Planning}

Typically in a Learning History, a senior manager or intervening consultant is identified to lead the "research" aspect of the group's project. If an internal person is tapped, he or she will usually keep whatever their organizational title is, although it is acknowledged that there is now a dual role in terms of their organizational duties and the researcher role. Ideally, the outcome of a Learning History is to aid in the process of reflection in attempts to evoke an institutional or cultural change.

In this study of the WVU 2013 Solar Decathlon team process, the research leadership role was assumed by the team's Project Manager. The Project Manager's general responsibilities are to keep a timeline, maintain communication among team leads and to generate tasks for the team. As stated in Chapter 1, the 2013 Solar Decathlon was WVU's first entry into the competition, thus making it a pilot project. In the summer of 2012, WVU was already identified as a competitor for the 2013 Solar Decathlon, and 
was in desperate need of a project manager. Though not a part of the WVU team proposal, when the researcher was selected to fill the Program Manager position, the process of creating a Learning History began.

\section{Phase 2: Research}

Given the researcher's professional interests in reflectively helping companies to become 'more green', the 2013 Solar Decathlon presented an opportunity to fulfill this reflective process through the creation of a Learning History. In terms of preparing this experience as a Learning History, the researcher approached the competition with a methodological framework. The researcher approached daily tasks keeping in mind that in the end, the study would require several data sources.

a) Primary sources, such as journal entries and notes about daily tasks completed, success, obstacles and barriers, and trouble-shooting tactics; correspondence within the team; and the project Manager's correspondences on behalf of the team (for example, with advising faculty from several schools /departments, community sponsors, consultants, the WVU Research Center's Project Management team, and more.): These are the basis for selecting Milestone Events, and these are the basis of participation reflection and interpretation.

b) A qualitative questionnaire: This tool was developed to collect reflections and interpretations about the group's process as distilled in the Milestone Events.

c) Primary sources such as university-authored web postings related to the Decathlon: These are needed to determine how, if at all, the Decathlon contributed to the WVU portfolio of commitment to sustainability.

The project / study process generated a high volume of paper and electronic records, sometimes called "artifacts". The researcher maintains these in several organized electronic and paper storage systems (e.g. password-protected e-mail accounts, thumb drives) and lock-and-key storage cabinets or boxes. 


\section{Phase 3: Distillation}

From the primary source archive, and especially from the researcher's notes, a questionnaire was generated. Reviewing the Project Manager's notes, a set of Milestone Events was indicated, often marking turning points in the process, such as completion dates, deliverable due dates, project completion segments, trainings, and project-related university events. These were narrowed to the final set of events by considering primary documents (correspondence) related to the events.

The final set of milestones was presented for reflection in the form of a questionnaire, which met the requirements of the Institutional Review Board (IRB). As is required by the IRB, a script and cover letter (Appendix A) was generated for consistency and continuity, as follows:

The below are milestone events that were part of the 2013 Solar Decathlon competition. Please read the event descriptions to familiarize yourself with the milestone, then give your opinion: whether it was a good or bad thing and why, what we should have done, or NA because you were not involved with the given milestone (i.e. If I say I downloaded Revit...respond with if you downloaded Revit, or that you downloaded it, but didn't use it, etc.; or if I say that I spoke with the dean of my college, respond with your conversation with the same dean, or...) (Study Survey, 2014, p. 1)

The questionnaire asked for reflective responses to each of 33 chronologically presented Milestone Events. The questionnaire also asked the title of the respondent's decathlon team position during the competition (as an identifier, instead of using name, to protect members' identities). Four other questions were asked to get at whether or not the researcher light have missed vital Milestone Events, in order to capture any recollections or impressions that might have been formed as the questionnaire was completed, in order to shed light on earlier responses to Milestone Events. 
Q2. What was (were) the overall successful aspect(s) of the project?

Q3. What was (were) the overall unsuccessful aspect(s) of the project?

Q37. Are there any significant events that we were involved in, that was (were) not included?

Q38. Is there anything significant about the project that you would change?

The questionnaire was sent and returned in the form of a Microsoft Word document attached to email. These were conducted electronically for at least three reasons: 1) the method was a green/non-wasteful way to collect data, 2) the method reduced problems relating to transcription and translation, and 3) the WVU IRB suggested this option to keep sensitive data secure within the WVU network.

Five criteria were used to identify a purposive sample - to go directly to those participants who had the greatest depth and breadth of knowledge about the project, and who were most likely to be invested in making the process better for the next group.

1) At least one year (similar to the researcher's role) of involvement in the team

2) In a titles leadership position for at least part of that time

3) Involvement included the summer work period, for continuity

4) Traveled to California for the event

5) Were still enrolled at WVU in Spring 2014

Including the researcher, five individuals met the selection criteria for the questionnaire portion of the study. To confirm that the selection criteria did tap into the expertise needed, the roles of the five qualifying individuals are reviewed here. 
- In addition to the Project Manager role, the researcher was also assigned duties that came under several subtitles: Sustainability Manager, Administrator, Health and Safety Officer, and Architectural Project Manager. He was involved with the Decathlon in less central roles for several months before being selected as Project Manager.

- The Design Lead Coordinator (DLC) coordinated the design teams, including Interior Design, Landscape Architecture, and Fine Arts.

- The Electrical Engineering Leed (EEL) coordinated several teams, including Electrical, Heating/Ventilation/Air Conditioning, and Home Automation.

- The Public Relations Contact (PRC) began as an engineering member, then moved to the lead for the HVAC team and PRC

- The Landscape Architect Lead (LAL) generated the design and oversaw all vegetation related to the house, like the planters on the deck, the green roof, and the living wall.

Individually and collectively, these individuals occupied roles from which they experienced more deeply than most other participants the complexity of the "project" experience. As mentioned, the questionnaire did not ask for personally identifying information such as names, age, or gender. Four participants were undergraduates, and the participant researcher was a graduate student.

After questionnaire data was collected, all responses were compiled into a single master document. Respondent review was conducted by sending the entire response set to the respondents and inviting further comment or correction if their responses had been entered incorrectly. This was unlikely since responses were pasted directly from the returned electronic documents. There were no corrections / changes, and all participant responses confirmed the accuracy of their response within the dataset.

With this dataset the following steps were used: 
- Responses to Q37 (Are there any significant events that we were involved in, that was [were] not included?) were scanned for indications of missed milestones. None were identified.

- Milestone Events were scanned for indications that the researcher included milestones that were not viewed as significant by the group. This type of error was identified as Milestones to which no other, or only 1 other, participant responded. This analysis excluded Milestone Events 7, 8, 9, 11, and 31.

References to Milestone Events from here forward only include responses to the remaining 28 Milestone Events. A directed content analysis strategy was applied to the reduced dataset. As is custom in a Learning History, the general groupings were created by the primary observer/researcher. Two directed analysis frameworks were developed and applied. The first is drawn from the three categories of resources that a Project Manager is to allocate (social, material, economic). The second analytic framework applied was drawn from the interpersonal skill-set associated with successful project management. Both frameworks were described in Chapter 2.

\section{Phase 4: Writing}

The goal of a Learning History is to create, through a narrative, a clear and concise account of a specific event. This is accomplished by sorting data, translating and interpreting useful data, analyzing that useful data, and finally writing and rewriting the data into a narrative form which is meant to be read as a story. The writing of a Learning History is to be accessible to a specific audience. The specific audience for a Learning History is members of the same organization as the researcher. The intended audience is essential to the writing of a Learning History and should be considered throughout the writing process.

\section{Phase 5: Validation}

To check and show validity, several steps can be taken. The respondent review described in Phase 3 is one example. Ideally, participants also have the opportunity to 
read drafts of the "results" of their work, and to influence how the results are interpreted and used. Unfortunately, no further validation steps are taken in this study. The main reason is that the researcher's access to participants ended. According to the original project advisor, this is not unusual for a project at an undergraduate college, but it is still not ideal. Upon graduation, students tend to sharply decrease or end use of their institutional email accounts, and other means to follow up are not within the IRBapproved participant contact techniques for the study.

\section{Phase 6: Dissemination}

Ideally, a Learning History study will include review and conversation with local scholars (those familiar with the context of the project). Especially after your study is complete, it's important to share your complete study with scholars who have contributed to the work, and to ask their thoughts on how it can be useful beyond the organization, if that is an option. For two reasons, dissemination of this study will be modest. First, the researcher has scholars who originally advised this project. Some have left the institution. Second, the biennial nature of the Solar Decathlon competition creates a lag in the relevance of the project. Interest will likely increase in the proposal phase for each new round, and decrease in the intervening year.

\section{Phase 7: Publication/Outreach}

Ultimately, the end goal, through reflection of the event, is to guide the audience to improved future participation of similar events of the same organization (WVU). For reasons noted in the description of Phases 6 and 7, there is little likelihood that the experiences and expertise of developed by the 2013 Solar Decathlon team will "live on" in members of the community for the future competitions. That is why it is especially important that this study will be available for future participants through the WVU Thesis and Dissertation database. Though it will be available more broadly to the limited interested audience who have access to the database, its primary and legitimate value is to the WVU community. In addition to the value this study may hold for future WVU Solar Decathlon teams, the project itself has demonstrated value in the WVU portfolio related to its stated commitment to sustainability. This value was summarized in 
Chapter 2, and as in academic product, this study adds to the institutional portfolio.

The below graph, created by Kleiner and Roth for their Learning History website (http://ccs.mit.edu/lh/intro.html) that gives a visual representation of the phases.

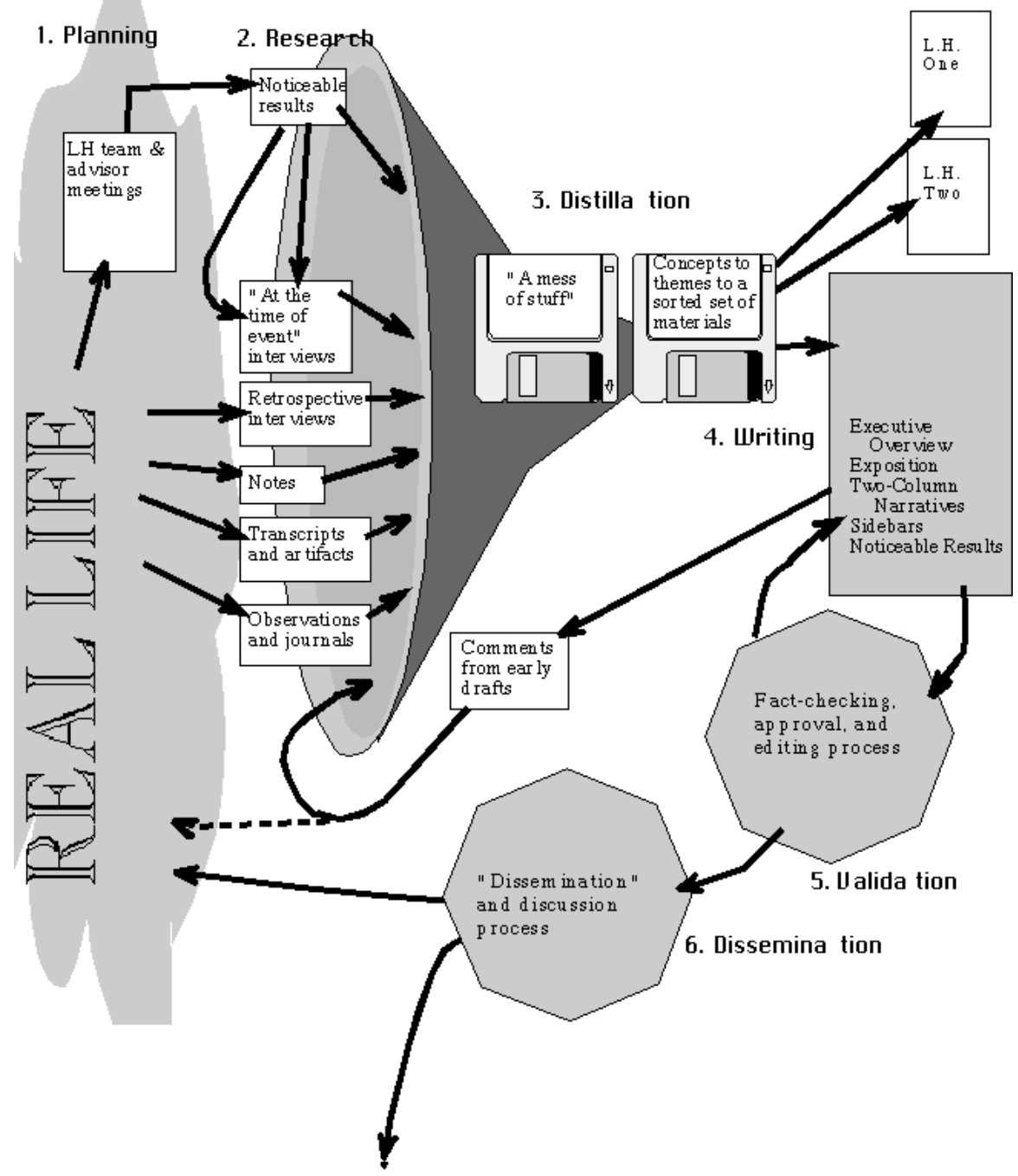

7. Pub lica tion/outr each

Figure 3: Anatomy of a Learning History Project: http://ccs.mit.edu/lh/: Intro 


\section{CHAPTER 4}

\section{Results}

Directed content analysis was applied to the dataset of responses to a 38-item questionnaire. The questionnaire was distributed and collected as an e-mail attached Microsoft Word document.

Question 1 pertained to the respondent's final role on the West Virginia University 2013 Solar Decathlon team. All respondents provided responses to the substantial majority of the 38 items, indicating an ongoing desire to contribute to the success of future teams. Responses to this item have no additional analytic value.

\section{Directed Analysis: Effective Management of Project Resources}

All content was repeatedly scanned for relevance to the three categories of resources available to a Project Manager: social, material, and economic. While recognizing that the three categories interact, it was surprisingly simple to identify a main relevance for the Milestone Events and participant reflections.

Among the Milestone Events, I was surprised to find that only two address the issue of economic resources. One of the two events was omitted from analysis because no more than one respondent found it relevant enough to comment upon, leaving only one event identifiably related to economic resources.

Milestone 20: After calculating all of the lumber would be needed to build the house, the company that we had agreements to donate lumber for us backed out on the eleventh hour. So we made a mad dash to contact every local company with hopes that they will donate or give us reduced costs on lumber. 
This milestone is double coded as economic and also material. In all, five events pertain to material resources and their management, and all five are among the 28 final Milestone Events. The other four are:

Milestone 3: After emphasizing the importance of being sustainable whenever possible, leads began looking for materials including: reclaimed timber, FSC lumber, recycled and composite products, and energy efficient appliances.

Milestone 13: I pushed for metal roofing for it is more sustainable than shingling, it was discussed and decided I was right. We also discussed using a solar water heater as a preheater for the house. I also push for an in-line wanter heater, but because a sponsor was supplying that hardware and they didn't have them (we did not get it).

Milestone 15: I remind the LA about the help that is available for the vegetation because it's indicated to me that there was no communication. This continued to be a problem, this is partly because we continue to have issues with the Communications group. They still haven't finished the donor packet and don't communicate to donors as supposed to. We continue to ask and to stress to their advisers that work is not getting done, all to no avail.

Milestone 23: We continued work on the master material list, adding whether we got the item or not.

The remaining 23 Milestone Events deal with social resources and social resource management. These remaining events will be discussed next. 
This analysis does match my retrospective experience of which aspects required the most time or energy in the role of Project Manager. Both my reflection and the evidence from this unintentionally authenticating result lead to another logical analysis phase one focused on the set of interpersonal skills necessary for successful project management. I interpret these as the skills most necessary for managing the third category of project resources - social (people).

There are two aspects of managing a project's social resources. The first issue is quantity - how much you need when and where. The project needs enough people to complete the tasks that will end with the project done, and you need them in the right roles or places at the right time. These pieces are essentially about managing supply and deployment. The second overall issue is quality - the quality of interactions among the people, and their effectiveness in getting the tasks done both independently and as a team or group.

In reviewing the 28 Milestone Events, eight are identifiably associated with the issue of recruiting and deploying the project's social resources; six are identifiably associated with the effectiveness of those social resources; and 12 of the events are of a more procedural nature. Thus, more than half of the events pertain to the quantity and quality of the project's social resources. Social resources were, then, a significant focus of the project. One event is coded as pertaining to both deployment and quality of social resources (marked with ${ }^{*}$ ). Recall that five events are associated with the management of economic and/or material resources in the preceding paragraphs. 


\section{Milestones Related to Recruiting and Deploying of Social Resources}

Milestone 1: The team lead sent out rules and building codes documentation for the $S D$ competition and asks all leads to read them all over.

Milestone 2: SD leads gave presentation to the Energy Club to recruit.

Milestone 5: We began processes for the transition of leads, this happened every semester and sometimes more often.

Milestone 12: We struggled to find a time that we could all meet for leads meetings.

* Milestone 14: I stressed that we needed to start reaching out to our various university media resources to help with university support and recruitment. I assigned a member to lead this task and gave periodic inquiries on progress, but the member did not follow through.

Milestone 18: We continued to have regular meetings, this is another thing we did well.

Milestone 25: With the generous and most appreciated help from our new structural engineers and after assisting Lawson-Burke with drawings from the Revit Model and creating sheets for the BIM, we successfully submitted Stamped Structural Calculations and Drawings to the DOE.

Milestone 32: Began the disassembly of the house, we had 5 days to tear down the house and erase all traces that we were there (except the holes we drilled for anchoring). We did this exceptionally well, having no issues except for the fulcrum collapsing and breaking to pieces. 


\section{Milestones Related to the Quality and Effectiveness of Social Resources}

Milestone 10: Several leads still have not read over the rules and building codes documentation, so I emphasize the importance that they all read them over.

* Milestone 14: I stressed that we needed to start reaching out to our various university media resources to help with university support and recruitment. I assigned a member to lead this task and gave periodic inquiries on progress, but the member did not follow through.

Milestone 15: I remind the $L A$ about the help that is available for the vegetation because it's indicated to me that there was no communication. This continued to be a problem, this is partly because we continue to have issues with the Communications group. They still haven't finished the donor packet and don't communicate to donors as supposed to. We continue to ask and to stress to their advisers that work is not getting done, all to no avail.

Milestone 16: We had issues with the members not showing up to their 10 hour safety training: coming in late or not showing up for one of the three training sessions.

Milestone 22: I continued to have issues with getting members to attend OSHA training, this was understandably conflicting with and aggravating for both SHE and myself.

Milestone 26: After getting a message from the DOE warning us that if we do not get our revisions completed and approved to our BIM we would be disqualified, and after a week of near around the clock, working on Revit by the researcher and an Electrical Engineering student also familiar with Revit, were able to complete the BIM to success. 


\section{Milestones that are Primarily Procedural, though not Unrelated to Social Resources}

Milestone 4: I download the Autodesk architecture program Revit, and began familiarizing myself with it.

Milestone 6: We began work on our revisions on the deliverables: BIM, Project Manual, and Revit Model. Consistently, we waited too long on starting our deliverables, we should have started these weeks beforehand.

Milestone 17: We also discussed the need for the BIM to be National CAD Standards compliant.

Milestone 19: We submitted our second set of major deliverablesConstruction Documentation: BIM, Revit model, Project Manual, HSP, and revised Cost Estimate.

Milestone 21: I continually was the one to go to for information in all aspects of the house like measurements, area, volume, square footage, linear footage, materials, layers, location, placement, angles, etc.

Milestone 23: We continued work on the master material list, adding whether we got the item or not.

Milestone 24: After working on the HSP tediously, and after learning how to write it, I was able to complete the plan, successfully, to the DOE's requirements.

Milestone 27: Those of us that were going to the competition begin the registration process. 
Milestone 28: Soon after finishing all of our deliverables, we are hit with several email messages from the DOE regarding preparation for the competition:precompetition meetings, sub-contest information, and various other information. This was good to get at this time because it kept the group on track and helped to solidify the reality of it all.

Milestone 29: We book our plane tickets and secure hotel rooms for the four weeks that we will be in competition, this got the members thinking about the competition and their roles and got everyone excited.

Milestone 30: We receive news that team Tidewater Virginia will be unable to compete, We feel bad, knowing what we had gone through but still able to compete, it must have been pretty bad for them.

Milestone 33: We flew back to Morgantown with everyone accounted for.

Further review indicates that responses to the events categorized as procedural in nature commonly view the event in terms of its reflection of, or effect on, social resource quality or effectiveness. A second directed analysis process was followed to more closely understand the social resource management aspects of the study. 


\section{Directed Analysis: Importance of Project Management Interpersonal Skills}

As noted in Chapter 2, The Project Management Book of Knowledge (Project Management Institute, 2013) lists a set of research-supported interpersonal skills necessary for success. Alphabetically, these are: coaching, communication, conflict management, decision making, influencing, leadership, motivation, negotiation, political and cultural awareness, team building, and trust building. Of the 11 skills, all are evident explicitly or implicitly in the dataset, and six stand out.

Communication: Every respondent identified communication as an issue, and in particular as a barrier to project success, taking top spot in the "unsuccessful aspects" at Question 3:

-PRC: The biggest setback we had were communication issues and not enough people to get the deliverables don on time.

-LAL: The communication between teams and individual team members was something that struggled all the way until the final deconstruction day.

Throughout the remaining milestone responses, communication in some way was cited as a problem 29 times.

Decision Making: References to decision making are made frequently during the responses, often forming committees when deciding that something needed to be done. As seen on Milestone 17.

-PRC: If there was a group, I was definitely on it in terms of NCS compliant. I've explained my situation in this. The only thing that could have helped our consistency issue would have been to work in NCS templates earlier. -LAL: When we began to use the standards, our BIM began to carry a consistent look, one that we did not have for any other deliverable prior to that use.

Throughout the remaining milestone responses, decision making was cited an additional 15 times. 
Influencing: Throughout the responses there are evidence that suggests the result of influence. Such as in Question 38.

-DLC: I would contact prospective donors for design materials myself instead of getting them thrown on the back burner. Communication needed changed a lot. Storage space and/or an indoor building location.

-PRC: There are a few things that I would change. In general just how to handle certain things, when to start preparing the team for a specific task, how to enforce work, etc. It's a learning process for everybody through the 2 years of the project.

Throughout the remaining milestone responses, influencing related comments were cited an additional 7 times.

Leadership: The leadership responses were both positive and negative, as can be seen in Milestone 5.

-EEL: Our transitions were not transitions but a violent metamorphoses and no clear way of passing on knowledge.

-PRC: As the leads changed, it wasn't a big problem for me if it was addressed to the team. For example when a student lead graduated, and the entire team knew who would be taking their place. The dynamic of the individual teams changed but it wasn't too bad to handle.

Throughout the remaining milestone responses, comments related to leadership was cited an additional 10 times.

Motivation: Every respondent has an entry that describes motivation of some kind, mostly from positive inspirations, like Question 2:

-DLC: Completing construction in Cali, learning new things

-EEL: The level it got to, the outreach, the sponsorship, the

teaching it provided, the networking, providing new ways to think.

Throughout the remaining milestone responses, comments related to motivation was 
cited an additional 39 times.

Trust Building: The responses on trust building are positive in nature, as can be seen in Milestone 21.

-PRC: N/A- No one came to me for that, I went to others (DLC or PM).

-LAL: There was a good system in place: having (PM) in the office and someone to correspond with on site for measurements so that upon completion, our house closely resembled our model in Revit.

Throughout the remaining milestone responses, comments related to trust-building were cited an additional 18 times.

\section{Other Thematic Observations about the Dataset}

Though not asked to do so, all respondents spontaneously indicated that the Solar Decathlon team experience is one they value highly. For some this value is seen to be in spite of project difficulties, while for others the value is in part due to the learning associated specifically with the challenges.

Q2 Results LAL: The most successful aspect of the project was the amount of teamwork an perseverance shown throughout the design, construction and competition phases.

M33 Results PRC: It felt great to be back having competed and actually completed the house. We had a lot of setbacks in the competition but we still succeeded in so many other ways. For me the point was to go out there and represent WVU, and we did. So little people will know what we went through in the 2013 competition, but the bond we formed as a team will never be forgotten. It's definitely the most I have taken from the project.

\section{Conclusions}

Based on the results described in this chapter, the research questions are reconsidered, the first question: 
- In what ways was the Solar Decathlon 2013 team experience consistent or inconsistent with good practice in terms of Project Management?

For this question, you can see proof of Leadership in one, and Team Building in the other, two of the Project Management tasks, below (seen earlier).

Q2 Results LAL: The most successful aspect of the project was the amount of teamwork an perseverance shown throughout the design, construction and competition phases.

M33 Results PRC: It felt great to be back having competed and actually completed the house. We had a lot of setbacks in the competition but we still succeeded in so many other ways. For me the point was to go out there and represent WVU, and we did. So little people will know what we went through in the 2013 competition, but the bond we formed as a team will never be forgotten. It's definitely the most I have taken from the project.

The second question:

- $\quad$ Could a Learning History approach have value (produce transfer of organizational knowledge) if built into future Solar Decathlon team processes?

You can see evidence of this by looking at the responses of the this study, and taking its advise (two examples below). Further insight could be taken by repeating the process.

Q3 Results PRC: The biggest setbacks we had were communication issues and not enough people to get thee deliverables done on time.

M10 Results EEL: It is above anything that the leads read and reread the rules and building codes. 


\section{CHAPTER 5}

\section{Discussion and Recommendations}

Chapter 4 identified problems that occurred during the 2013 Solar Decathlon competition. Through analysis, findings and details of these problems were explained. This chapter will give general summaries of these findings then put these findings into practical perspectives. From these perspectives, recommendations will be presented for the purpose of learning and building from the experiences detailed in this study. Finally, the chapter will end with suggestions of relatable studies that can be done in the future.

\section{Generally}

One overall problem that was discussed in Chapter 4 was recruitment. Although this is a relatively new competition and especially new to West Virginia University, future Solar Decathlon teams need to be filled with members who take the competition very seriously, and treat all responsibilities with dedication. To achieve this through recruitment and coaching, the qualifications for the Project Manager should emphasize the interpersonal skills of motivation, influencing, leadership, team building, coaching, and especially communication.

Issues related to the leadership of the team cannot be ignored. The ability to see a task from start to finish at a glance, anticipating needs ahead of time, and obtain/use resources correctly were all issues that the leadership struggled with. The team leads will need to make sure they have a back-up plans and redundancies in case things go awry, and they need to ensure that all members that have duties also have someone to take over responsibilities if they are unable to complete the duty. Being well organized is essential, everything dealing with plans and actions needs to be well thought out, carried out diligently, and follow-ups carried out on a regular basis. 
One of the biggest issues that the entire project had was communication. It will be essential for team members to communicate to other team members, to other teams, to administration; for teams to communicate to other teams; for administration to communicate with the university and sponsors; and this all needs to be accomplished frequently.

Another area that will be essential for success will be a serious commitment from the University. The team has got to have support and backing from the university in future competitions. This support needs to be on both a large and small, macro and micro scale. The University as a whole needs to support the project, and each college and department involved needs to contribute their support in the efforts. There were far too many issues that would have been resolved, and better yet, avoided, had the support been there and given.

The last area of focus that will be discussed in this section is a lack of outside commitment. This meaning some companies and individuals under contract with the team, sponsors, donors, and the like tended to back out of their obligations. I realize that it's hard to prevent this, and that it sometimes just happens. But a way to help prevent the issues that it causes is for the leads to have a contingency plan to replace the individual/company if necessary, or perhaps involve the WVU legal department when involving third parties.

In general, I agree with all that was said regarding the responses. I have a lot of pride for the team because although we faced adversity and people refusing to believe we could do it, we were able to get the house built and fully functional. This was an amazing experience and opportunity for me, as well as other members. But it was only an opportunity; if members did not take advantage of the opportunity, they did not get as much out of the experience as they could have. I put everything into it because I wanted to get as much out of it as I could. I would advise that future members take the 
competition very seriously and deeply obligate themselves and immerse themselves in the project to get as much out of it as is possible.

The next section will be descriptions of specific issues, followed by instructions and scenarios to discuss what would have happened, ideally, had this information and experience been known. It will also be a discussion of what to be sure to do in future competitions.

\section{Specifically}

In Chapter 4, three basic categories for the issues were discussed, these were described as:

-Recruiting and Deploying of Social Resources, which is a category that includes issues relating to recruiting, retaining, and engaging advisers, contractors, leads, and members;

-Quality and Effectiveness of Social Resources, which includes issues relating to advisers, contractors, leads, and members taking the competition seriously; lastly,

-Primarily Procedural, though not Unrelated to Social Resources, which includes issues relating to advisers, contractors, leads, and members not following through--or waiting to the last minutewith commitment obligations. 
In this circumstance, advisers are described as non-student individuals, both university and non-university related, that the team used as subject matter experts. Similarly, relating to this study, contractors are described as third-party individuals or companies hired by the university or obligated via donations to aid in the project. Finally, leads and members are students of WVU that were involved in the project.

Upon further inspection of these issues, the general categories can be expanded into five more specific problems. The five problems are:

-lack of perceived importance by the team members,

-lack of team member commitment,

-lack of perceived importance by sponsors,

-lack of university support, and

-lack of organization/communication.

It is to these problems that I will describe, and give perspectives and recommendations.

Through this further inspection, I discovered that the solutions cannot come solely from a Sustainable Management perspective, for solutions, project management must be utilized. Project management, as discussed in Chapter 2, has three basic resources: social assets, environmental (or material) assets, and economic assets. Since the five problems discussed above are social in nature, social skills must be employed. The skills are (discussed in Chapter 2): coaching, communication, conflict management, decision making, influencing, leadership, motivation, negotiation, political and cultural awareness, team building, and trust building. The phases that project management is based off of must also be used (in Chapter 2): Initiation, Planning, Executing, Monitoring, and Closing. Future project managers must bring all this together for each individual task that needs to be completed and each issue that may arise to sustain a successful project. 


\section{Lack of Perceived Importance by the Team Members / Lack of Team Member Commitment}

The first problem is lack of perceived importance. An example of this would be that a member agrees to call potential donors for a particular product, like sustainable siding for the exterior of the house, and decides that it's not worth their time. The next problem: lack of member commitment, is similar. An example would be that a lead repeatedly misses meetings because they don't like them. These two problems can be resolved with the same procedures that will be discussed next, but each problem must be considered separate and given its own amount of attention by the PM.

This problem resides in recruitment of members and leads. When the member or lead agrees to be a part of the competition, they must do so only after they are made aware that they will be responsible for tasks that they agree to carry out, and that they will need to invest time to fulfill tasks. It will be the responsibility of the PM to ensure that whoever recruits members will communicate these points. It will also be the responsibility of the PM to follow up with the recruit so that these points are understood. After the information is communicated and agreed by all parties, the recruit becomes a member. Another necessity will be for both the PM and team leads to ensure that there is a contingent person to assume responsibilities in the case that the member/lead can no longer continue with their responsibilities. This means that all tasks need to have a minimum of two people working on it, even if one is just a helper that is made aware of the duties being performed.

The phases to use for this problem include:

-planning — set a goal with the member/lead, include:

start dates, goals, progress reports, intervals, completion dates, helper/teammates, and anything else that may be needed, -execution-ensure that the work is being done, and follow up to ensure execution was completed, -monitoring - both the member/lead and the PM need to monitor that tasks are being accomplished. 
The first phase, initiation, for this problem, is already accounted for when the recruit/member/lead agrees to take on the task, and closing will be discussed later.

The skills that must be used for this problem are:

-coaching (tell them what's going to need to be done, get as specific as you can),

-communication (check-in with the member/lead, and ensure that they are doing any communication that they may need to do), and -motivation (the member/lead may be reluctant and/or intimidated to take on the task, reassure them that it is possible and that they can do it).

\section{Lack of Perceived Importance by Sponsors}

The next problem is lack of perceived importance by sponsors. An example of this problem might be a wood donor who decided that after committing to the project, decides that they are no longer interested. Sometimes this issue cannot be avoided, sometimes a donor's budget or priority changes. Similarly to the first problem, a contingent donor needs to be researched and talked to in case the primary donor rescinds. But in some circumstances it's because of reasons that could have been avoided. When a member/lead manages to interest a donor, they must maintain that donor's enthusiasm. This can be accomplished using the following phases and skills.

When implementing phases with this problem, initiation is achieved when the member/lead establishes the donor. The next phase is planning, to effectively use this phase, establish:

-what will be donated (be very specific),

-how it will get to the build site, -when it will arrive at the build site, and 
-what the donor will get in return (a sincere 'Thank You' card should be sent at the very least).

The next phase, the execution phase, is used repeatedly:

-when the planning phase is completed and communicated to the donor,

-when each communication is made with the donor,

-when goods and/or services are delivered by the donor, etc.

The monitoring phase is achieved through the periodic communication that will be made between the member/lead and the donor; the PM must also monitor this communication to ensure it is maintained. Although managed by a professional university representative, there will still need to be a team member/lead that is involved throughout the process to help, learn, monitor, and report.

The skills necessary for this problem are:

-communication, you can keep the donor's interest by giving regular communication. This communication should be discussed with the donor so that it's not too often, but it's often enough.

-motivation and negotiation, these skills will be crucial when securing the donor, and less when maintaining the donor,

-trust building, one of the most important skills that will need to be used is trust building, especially after a donor is secured. The member/lead must spend time assuring and reassuring that the donors value is appreciated and that any agreement (whether endorsement on a website or flyer, or tax write-off documentation, etc.) with them is fulfilled and maintained. 


\section{Lack of University Support}

The next problem is lack of university support. This was a complicated problem that is understandable and wasn't necessarily one that could have been avoided, but was still a problem. People only have so much time to spend on obligations that bordered near extra-curricular, but a commitment was made by the university, so support is obligatory. An examples of university support is having an office room big enough for all teammates to work together. Instead, our team had various makeshift room offices scattered throughout the campus. Another example is having a stable build location, or having storage facilities enough to house all of the materials needed, or providing information and knowledge when asked.

The initiation, planning, execution, monitoring, and closing phases are straight forward. Initiate the task by determining what you need, plan the task by coming up with how the university can help with what you need, execute the task by making the request, monitor the task by checking with the university until the request is fulfilled, and close by, at the very least, sending a sincere "Thank You' card. In conjunction with the phases, in order to combat this problem, many PM skills must be used.

The necessary skills are:

-communication, there needs to be a liaison between the university administration (President, Provost, etc.) office and the team administration (Principal Investigator, Team Lead, PM), someone to relay the needs, concerns, and questions back and forth.

There also needs to be a liaison between each college administration (Dean, Director, etc.) and the team administration for the same reasons. I feel that there was a disconnect between the team and the university administration, this would eliminate any disconnect that the team would have and augment the goals of winning the competition that all of the university had, 
-decision making, this must to be employed to decide when communication and/or help is needed,

-leadership, especially by the PM, must be used to represent the team that you are speaking for and also to communicate to the team after communication is made with the liaison,

-motivation and negotiation, both are used here to maintain a balance between support that is needed and what can be done without university support,

-political and cultural awareness, this is important when deciding when and how to reach out to the university, lastly,

-team building, necessary to ensure that the university and college administrations understand the need for help.

I feel that one reason the team didn't get the support that it needed was because there was a large break in communication between the Solar Decathlon team and the office of the university president. It is known that the project was important to the university. This was demonstrated when WVU President, Jim Clements, stated during the ground breaking of the building site, "This project goes to the heart of what WVU is all about..." (2013, April 18). Retrieved from (http://wvutoday.wvu.edu/n/2013/04/18/wvu-solardecathlon-team-breaks-ground-on-solar-powered-log-home). While this was good for the university, it put great pressure on us which made us feel that the entire university, and to some extent, the entire state, was counting on us to not only finish the construction of the house, but to also do well during the competition. I feel that the pressure put on the team was not balanced with support from the university to the WVU Solar Decathlon team. 
I know that the president is a busy person, which is why I think that a liaison to just communicate to the president when possible would benefit. The liaison would communicate the needs of the team, like: a common office space, or a storage shed, or faculty support. The liaison would also communicate from the president, for instance: that he would like a photo shoot with the team, or that the university would like a certain part of the house done by a certain date. And even if the university is unable to help with a certain request, at least the team would know that there was communication and that the university tried.

Another help would be for the university to provide incentive to the professors, professionals, advisors, and the like, to keep them interested in helping. One way the university could supply incentive, is to count faculty support as contract fulfillments. Faculty, is required to devote large amounts of their time to teaching and research, their help could count towards one of these. This would give them the opportunity to conduct a study that could be published, or write a synopsis of their work and reflections of their experience, which could go out on university news.

\section{Lack of Organization and/or Communication}

The last problem to be discussed is lack of organization/communication. An example of this problem might be that a lead speaks with a donor, a change with what will be donated occurs, and the lead doesn't communicate the conversation to the team administration until the donated item arrives, or fails to arrive. Or if a member tells a lead that they have decided to quit, and the lead doesn't communicate this.

Looking at the previous problems, you can see that communication is mentioned again and again, which will help with organization. What is necessary is that when any member/lead does anything for the team, they need to communicate that to their lead, then that lead decides if it needs to be communicated to the next lead up (and when in 
doubt, communicate the information to the next lead). This can then be updated-if necessary-in the PM timeline. In order for this to happen the PM needs to communicate to every member and lead that after they do anything or represent the team in any way, they need to communicate this information.

A scenario of this successfully working is that a member talks to a donor and finds out that the donor will be unable to donate a certain item. This is then communicated to the member's lead, the lead then decides that the PM needs to know. The PM then tells the lead to contact the contingent donor for the product because it is needed. The PM then tells the team about the change during a weekly meeting. The finance and sponsorship team then adjusts the information to reflect the change in the necessary lists and the donation amount for tax write-off purposes. One of the members then says that they know of someone that has that product that can be donated. The PM then asks the lead if a replacement product has been found, the lead then confirms with the member that one has not been secured by other means. The team then gets the product from another source, all by simply communicating.

One way to keep both communication and organization in check is to have a detailed timeline. This level of detail needs to include: the smaller tasks like a monthly call by a member to a donor, to the larger milestone like the house successfully assembled by the deadline.

In order to communicate effectively, the PM will need to keep organized and will need to utilize the phases of project management to the fullest. The PM will need to think about initiation, planning, execution, monitoring, and closing for every single task that's brought forth, and think about how that task influences other tasks, and how each phase may influence any other task. Initiate the task by determining what the team needs. 
Determining what is needed will come naturally after you tell the group to communicate all needs to the team lead, then the lead will communicate that to the PM and others. Announce this during weekly meetings, or email, or whatever method is found to be effective, and reinforce it regularly. Plan the task by creating the necessary steps complete the task, and when the steps will need to be completed and communicate with the leads to find a set of steps that all believe will work. Execute the task by communicating and assigning these steps to the team. Monitor the task by checking with the assignees until the steps are fulfilled. Communicate via meetings/email/etc the steps that are scheduled soon. The close phase will be discussed later.

One great tool that can be used, especially for the phases of the project, is computer software called Microsoft Project. This program will help the PM to keep tasks and steps on a Gantt-like timeline to effectively juggle them all.

Additionally, when the PM is integrating and carrying out these tasks, they will need to utilize the interpersonal skills to the team's advantage. These skills are once again: coaching, communication, conflict management, decision making, influencing, leadership, motivation, negotiation, political and cultural awareness, team building, and trust building. With each task, and each step of each task, the PM will need to look at each skill mentioned to determine all that will be needed.

Earlier in this chapter, I mentioned that the final phase, the Closing Phase, would be discussed later, below is that discussion. The final phase of project management is the Closing Phase. This phase is imperatively important to celebrate a closing. From the smallest of tasks, to the largest of milestones, celebrate your completions. 
Even if it's in a weekly meeting where you tell the group that a member has reached out and began communication with a donor; or if a professional volunteers some information and/or consultation and they are sent a 'Thank you' card; that is an accomplishment. When a milestone is completed like the successful submission of deliverables or the building of the house is completed, have a party; celebrate; bask in the success. These increase and maintain morale, confidence, and satisfaction with the project; all necessary for successful completion.

A continuing quality that the team had was perseverance. Whenever there was a setback or someone that dropped out, there was always someone there to pick up the pieces. To an extent, this was because the team got lucky in that great people were part of the group. But it came with a cost to those that stayed and was taxing both physically and mentally. This can be avoided in the future by following these recommendations. 


\section{Future Studies}

After the work done here, it occurred to me that several other studies could be done relating to this one, here are some of those ideas for other studies. These four possible studies are described below.

- One future study would be to take what has been done here, use it for the 2017 Solar Decathlon competition. Then use the 2017 Solar Decathlon as a platform for another study like this, and build from that, and so forth. To take this idea further, you could then compare these studies or continue looking for similar studies to compare. Then use this combined information to start a universal Solar Decathlon (or similar) guide for use in future and/or current decathlons.

- Another possible study would be to rate the effectiveness of the DoE rules and regulations, then report that study to the DoE for their use in future competitions. For example, throughout the competition, we were faced with rules set by the DoE, some of these rules were clear, some were vague and/or ambiguous. While the DoE was always available to answer questions, many of these questions could have been avoided by augmenting or rephrasing said rules. This study could be an aid to rewriting those rules.

- One other study would be to analyze the green practices that the WVU 2013 Solar Decathlon team engaged in, conclude if they were as green as they could have been, then make recommendations to maximize future practices. In our team, there were many opportunities that we had to embrace sustainable practices, but, for whatever reason, did not. Like, we could have used a tank-less 
water heater, but went with a traditional water heater because it was donated. I think, especially because of the nature of the competition, that a study could be done to research and record all possible green technologies and practices that could have been done during construction of the house. The study would include what was used and what could have been used to increase the overall sustainability.

- A final study could be to research the experiences that other teams went through during the competition, and compare them with the experiences that WVU went through. The use of competition results as a baseline would be most effective, but overall satisfaction by the team should also be considered. One comparison could be the dates that phases were started, like when construction was started, or when work on deliverables was started. Another comparison could be based on university support, like if the team had a common work space, or if teams had faculty devoted to the competition, or any other university support. 


\section{Summary}

This learning history is a reflection and record of some events intricacies and analysis as a graduate student at West Virginia University of the 2013 Department of Energy Solar Decathlon. This study can be a guide that would benefit future teams to read for their experience in a Solar Decathlon competition, or as a resource for another study. 


\section{REFERENCES}

Boetti, G. \& Victor Leandro, V., (2008). Use of Social Network Analysis as a tool to evaluate success on construction projects and team interactions. University of Colorado at Boulder

Garkhail, R., (2014). Energy Performance Analysis of Ultra-Efficient Homes at Solar Decathlon 2013. Arizona State University.

Hawken, P., (1993). The Ecology of Commerce A Declaration of Sustainability. Harper Business.

Kleiner, A., \& Roth, G. (1996). Field Manual for a Learning Historian. Massachusetts Institute of Technology at the Center for Organizational Learning and Reflection Learning Associates. Website: http://ccs.mit.edu/LH/

Kolb, D (1984). Experiential Learning as the Science of Learning and Development. Englewood Cliffs, NJ: Prentice Hall.

Mulepati, S., (2013). A Case Study of Zero Energy Home Built for Solar Decathlon Competition. University Las Vegas.

Newman, J., (2014). Green Leader: James Newman. Retrieved October $15^{\text {th }}$, 2014. from http://www.greeningdetroit.com/wp-content/uploads/2010/01/Green-Leader-JamesNewman.pdf

Nidumolu, R., Prahalad, C.K., \& Rangaswami, M.R. (2009). Why sustainability is now a key driver of innovation. Harvard Business Review.

Project Management Institute. (2013). A Guide to the Project Management Body of Knowledge - PMBOK $5^{\text {th }}$ Edition. Project Management Institute, Inc.

Roddick, Anita. (2001). Anita Roddick > Quotes. Retrieved April 13 ${ }^{\text {th }}, 2016$ from https://www. goodreads.com/author/quotes/237031.Anita_Roddick. 
Sustainability Dashboard Tools, LLC. (2014). About Sustainability Dashboard Tools. Retrieved October $15^{\text {th }}, 2014$. from https://www.green2 sustainable.com/about

United States Department of Energy. (2012). SD2013 Rules v1.pdf Retrieved October 15 2014. from www.solardecathlon.gov/past/2013/pdfs/2013_rules.pdf

Wallpe, J., (2011). Evaluating Net-Zero Energy Houses from the U.S. Department of Energy Solar Decathlon 2011. Perdue University.

West Virginia University. (2015). WVU Mission. Retrieved June 20 ${ }^{\text {th }}$, 2015. from https://about.wvu.edu/wvu-facts

West Virginia University. (2015). WVU Vision. Retrieved June $20^{\text {th }}, 2015$. from http://strategicplan.wvu.edu/r/download/90091

West Virginia University. (2015). Office of Sustainability Vision. Retrieved June $20^{\text {th }}, 2015$. from http://wecan.wvu.edu/strategicplan/draft 


\section{APPENDICES}

\section{APPENDIX A}

Cover Letter

\section{WWestVirginiaUniversity}

Davis College of Agriculture, Natural Resources and Design

Dana Shearer (\# 1403250265, doc\# 95532)

Recruitment script/Cover letter:

Hello, as you know, I'm a master's student for the Davis College. One of the requirements for graduation is to write a thesis. In onder to do that, my thesis will be on experiences on and

recommendations on the Solar Decathlon 2013, and requires some opinions of some associates of the Solar Decathlon 2013 project. Because you are in a lead position, you traveled to California to participate in the competition, you were part of the group for at least one year without quitting, and yon wfere still enrolled the semester after the competition; I was wondering if you'd be willing to answer a questionnaire that familiarizes you with specific events and milestones during the competition and what your reaction is to it? The questionnaire is only for research, and you will not be identified in the paper: your name will be protected as well as your demographics; only identified by your position title.

If at any time you feel pressure or if you feel uncomfortable, you can stop the survey and tell me that you would prefer not to continue to panticipate. This is completely voluntary, so if you choose not to continue, or only answer some of the questions, there will be no consequences, repercussions, or retaliations; you are welcome to declime or stop at any time. Your responses will be kept discrete and confidential

The questionnaire will be conducted through secure email on university servers. Your class standing, grades, or job status will not be affected by refusing to participate or by withdrawing from the study. This letter and the questionnaire have been reviewed and approved by the Institutional Review Board (IRB). This project is research and is being conducted in partial fulfillment of the requirements for a master's thesis.

Thank you.

Dana Shearer

Division of Design \& Merchandising

Phone: 304-293-3402 702 Allen Hall

Fax: 304-293-2796 P.O. Box 6124

Morgantown, WV 26506-6124 Equal Opportunity/Affimative Action Institution 


\section{APPENDIX B}

\section{Questionnaire}

Shearer, Dana

Thesis 2014

Questionnaire

The below are milestone events that were part of the Solar Decathlon 2013 competition. Please read the event descriptions to familiarize yourself with the milestone, then give your opinion: whether it was a good thing or bad thing and why, what we should have done, or NA because you were not involved with the given milestone (i.e. If I say I downloaded Revit...respond with if you downloaded Revit, or that you downloaded it, but didn't use it, etc.; or if I say that I spoke with the dean of my college, respond with your conversation with the same dean, or the dean of your college...).

What was the title of your position during the competition?

What was (were) the overall successful aspect(s) of the project?

What was (were) the overall unsuccessful aspect(s) of the project?

What is your reaction to the following entry (Enter NA if not applicable): 09/23/12 - The team lead sent out rules and building codes documentation for the SD competition and asks all leads to read them all over. 
What is your reaction to the following entry (Enter NA if not applicable): 09/24/12 - SD leads gave a presentation to the Energy Club to recruit.

What is your reaction to the following entry (Enter NA if not applicable): 10/06/12 - I download the Autodesk architecture program Revit, and began familiarizing myself with it.

What is your reaction to the following entry (Enter NA if not applicable): 10/18/12 - We began processes for the transition of leads, this happened every semester and sometimes more often.

What is your reaction to the following entry (Enter NA if not applicable): 11/10/12 - We began work on our revisions on the deliverables: BIM, Project Manual, and Revit Model.

What is your reaction to the following entry (Enter NA if not applicable): 12/02/12 - I spoke with Dean Dan Robison of the Davis college about recruitment opportunities and Davis college involvement.

What is your reaction to the following entry (Enter NA if not applicable): 12/11/12 - We had our first fundraiser which proved not to help much. 
What is your reaction to the following entry (Enter NA if not applicable): 12/15/12 Several leads still have not read over rules and building codes documents so I emphasize the importance that they all read them over.

What is your reaction to the following entry (Enter NA if not applicable): 01/01/13 - After several unsuccessful attempts to get timesheets from leads, the PI tells me to devote my time to other responsibilities.

What is your reaction to the following entry (Enter NA if not applicable): 01/16/13 - We struggled to find a time that we could all meet for leads meetings.

What is your reaction to the following entry (Enter NA if not applicable): 02/03/13 - I stressed that we needed to start reaching out to our various university media resources to help with university support and recruitment.

What is your reaction to the following entry (Enter NA if not applicable): 02/14/13 - We submitted our second set of major deliverables-Construction Documentation: BIM, Revit model, Project Manual, HSP, and revised Cost EstimateWhat is your reaction to the following entry (Enter NA if not applicable):

What is your reaction to the following entry (Enter NA if not applicable): $07 / 19 / 13$ - With the generous and most appreciated help from our new structural engineers and after assisting Lawson-Burke with drawings from the Revit Model and creating sheets for the 
BIM, we successfully submitted Stamped Structural Calculations and Drawings to the DOE.

What is your reaction to the following entry (Enter NA if not applicable): 08/22/13 - After getting a message from the DOE warning us that if we do not get our revisions completed and approved to our BIM we would be disqualified.

What is your reaction to the following entry (Enter NA if not applicable): 08/31/13 Those of us that were going to the competition begin the registration process.

What is your reaction to the following entry (Enter NA if not applicable): 09/03/13 - Soon after finishing all of our deliverables, we are hit with several email messages from the DOE regarding preparation for the competition: pre-competition meetings, sub-contest information, and various other information. This was good to get at this time because it kept the group on track and helped to solidify the reality of it all.

What is your reaction to the following entry (Enter NA if not applicable): 09/09/13 - We book our plane tickets and secure hotel rooms for the four weeks that we will be in competition, this got the members thinking about the competition and their roles and got everyone excited.

What is your reaction to the following entry (Enter NA if not applicable): 09/11/13 - We 
receive news that team Tidewater Virginia will be unable to compete.

What is your reaction to the following entry (Enter NA if not applicable): 09/17/13 Items like Observer Logs and judges templates were emailed from the DOE weeks before we left to CA, items that would have given us advanced details to refine as we built and prepared for competition.

What is your reaction to the following entry (Enter NA if not applicable): 10/15/13 Began the disassembly of the house, we had 5 days to tear down the house and erase all traces that we were there (except the holes we drilled for anchoring).

What is your reaction to the following entry (Enter NA if not applicable): 10/20/13 - We flew back to Morgantown with everyone accounted for.

What is your reaction to the following entry (Enter NA if not applicable): 12/01/12 - After several attempts to secure training for professional presentation skills, the PM group tells me that they will manage this task, hoping that they will have better success with their available influence.

What is your reaction to the following entry (Enter NA if not applicable): 02/04/13 - I tell the Landscape Architect about the help that is available for the vegetation, because we are both eager to integrate it as much as possible. There also continued to be a 
problem, members and leads not communicating to the donors, this is partly because we continue to have issues with the Communications group.

What is your reaction to the following entry (Enter NA if not applicable): 02/04/13 - We also continued to have issues with Health and Safety. What is your reaction to the following entry (Enter NA if not applicable): 02/04/13 - We also discussed the need for the BIM to be National CAD Standard (NCS) compliant, here we should have and I suggested that we have a Deliverables group that checks all deliverables for consistency, standards, completeness, and submits the documents.

What is your reaction to the following entry (Enter NA if not applicable): 02/06/13 - We continued to have regular meetings.

What is your reaction to the following entry (Enter NA if not applicable): 02/06/13 - I continually sent questions to Joe Simon of the DOE and he was very good about answering them quickly.

What is your reaction to the following entry (Enter NA if not applicable): 09/30/12 - After emphasizing the importance of being sustainable whenever possible, leads began looking for materials including: reclaimed timber, FSC lumber, recycled and composite products, and energy efficient appliances. 
What is your reaction to the following entry (Enter NA if not applicable): 02/02/13 - I pushed for metal roofing for it is more sustainable than shingling, it was discussed and decided I was right. We also discussed using a solar water heater as a preheater for the house and I pushed for this.

What is your reaction to the following entry (Enter NA if not applicable): 02/02/13 - We also discuss making the house LEED Certified again, using one of our donor's employees whom was LEED AP Homes accredited, and it was agreed that we should.

What is your reaction to the following entry (Enter NA if not applicable): 04/09/13 - After calculating all lumber that would be needed to build, the company that we had agreements to donate lumber for us backed out on the eleventh hour. So we make a mad dash to contact every local company with hopes that they will donate or give us reduced costs on lumber.

What is your reaction to the following entry (Enter NA if not applicable): 04/10/13 - I continually was the one to go to for information in all aspects of the house like measurements, area, volume, square footage, linear footage, materials, layers, installation, location, placement, angles, etc.

What is your reaction to the following entry (Enter NA if not applicable): 04/30/13 - We continued work on the master material list, adding whether the item has been attained or not. 
What is your reaction to the following entry (Enter NA if not applicable): 04/17/13 - I continued to have issues with getting members to attend OSHA training, this was understandably conflicting with and aggravating for both SHE and myself.

What is your reaction to the following entry (Enter NA if not applicable): 08/02/13 - After working on the HSP tediously, and after learning how to write it, I was able to complete the plan, successfully, to the DOEs requirements.

Are there any significant events that we were involved in, that was (were) not included? Is there anything significant about the project that you would change? 


\section{APPENDIX C \\ Competition Deliverables}

\section{Appendix D Competition Deliverables}

The design deliverables consist of the schematic design summary, building information model, drawings, project manual, and audiovisual presentations. These design deliverables serve the following important functions:

- In its schematic design summary, the team shall disclose to the organizers all non-standard design features, communications strategies, site operations plans, and health and safety considerations that require further review prior to the continuation of the project into the design development phase.

- All the drawings shall be generated in an Autodesk Revit building information model compatible format.

- The drawings and project manual shall demonstrate compliance with the Solar Decathlon Building Code and the Solar Decathlon Rules so that the inspectors will be able to grant final on-site approval by verifying that the constructed project on the competition site was accurately represented by the approved drawings and project manual.

- The drawings and project manual shall clearly describe a team's proposed assembly and disassembly procedures. The site operations manager will review the teams' procedures to identify and address potential conflicts among the teams. Each team is encouraged to consult with the site operations manager as the relevant sections of the drawings and project manual are being developed.

- The drawings and project manual shall provide a residential contractor with all the information needed to generate an accurate, detailed cost estimate and to efficiently construct the building as the design team intended it to be built. The drawings and project manual must be comprehensive because the design team shall assume that the contractor has had no prior communication with the design team, has no prior knowledge of the design, and has little or no experience building high-performance residences.

- Because the juries have a very limited opportunity to evaluate the constructed projects on the competition site, the drawings, project manual, audiovisual presentation, and jury narratives provide the only means for a team to provide a detailed presentation of its project to the juries. In the weeks leading up to contest week, each juror shall evaluate the audiovisual presentation and sections of the teams' drawings and project manual relevant to the juror's respective area of expertise. The primary purpose of the juries' walkthroughs on the competition site is twofold: 1) to verify that the project, as assembled on the competition site, was accurately represented in the drawings, project manual, audiovisual presentations and narratives; and 2) to ask the decathletes any clarifying questions that arose during the evaluation of the design via the drawings, project manual, and audiovisual presentations.

Additional competition deliverables provided the information required to allow the organizers, juries, and public to develop a comprehensive understanding of each team's competition prototype. 


\section{APPENDIX D \\ Portfolio, Program, and \\ Project Management Interactions}

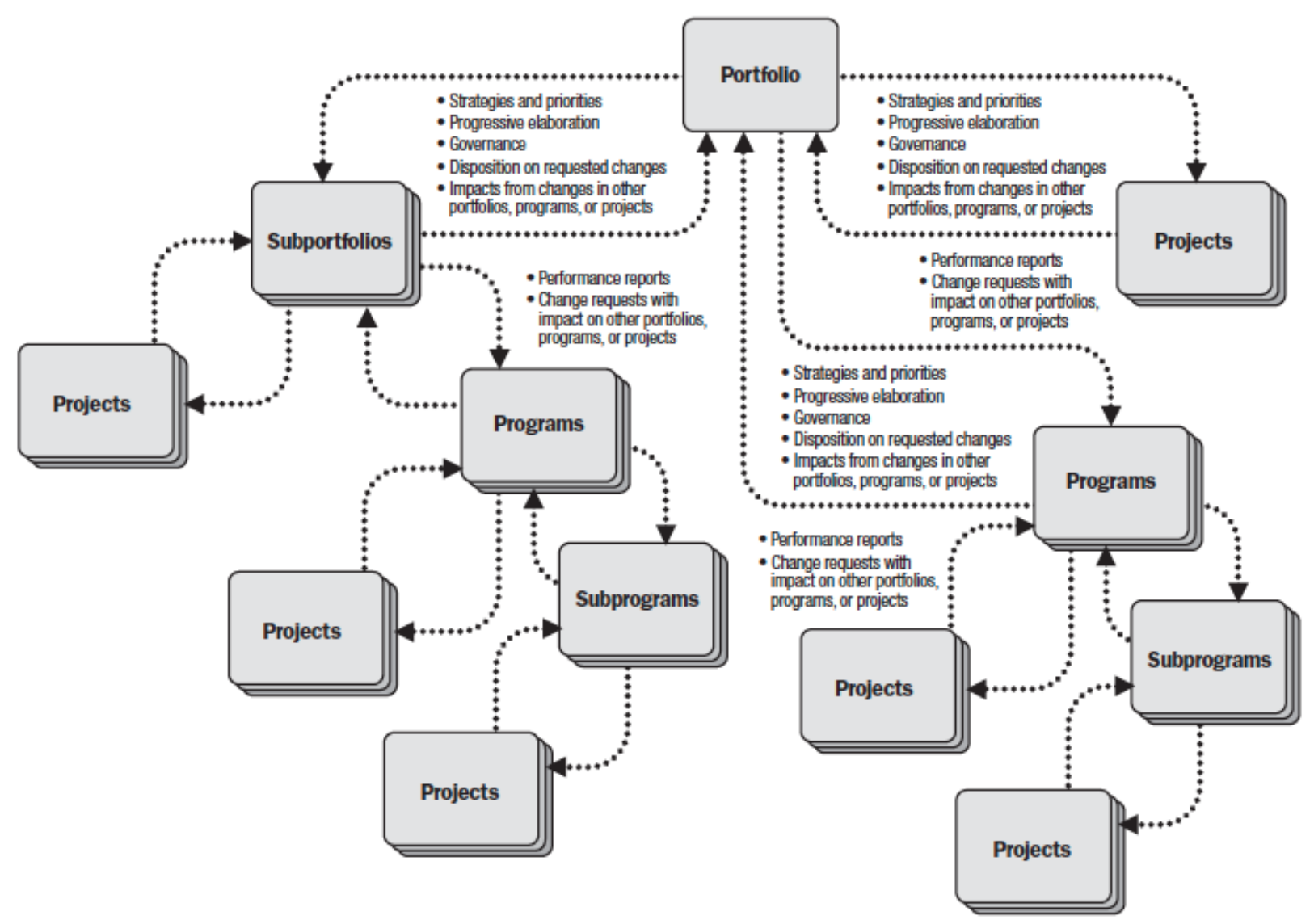

2013 Project Management Institute PMBOK Guide p. 5 Figure 1-1 


\section{APPENDIX E}

\section{Article Examples}

Agriculture college articles:

http://design.wvu.edu/wvu-solar-decathlon-2013

http://davis.wvu.edu/news/2013/5/10/in-the-news--solar-decathlon-team

http://design.wvu.edu/blog/2012/8/22/modern-meets-rustic-in-wvu-solar-decathlon-

team-s-design-for-energy-efficient-home

http://design.wvu.edu/blog/2013/8/30/wvu-solar-decathlon-readies-for-u-s--department-

of-energy-competition

http://larc.wvu.edu/laed news/2012/2/14/solar-decathlon-team-to-host-info-session-feb$\underline{-23}$

Engineering college articles:

http://cemr.wvu.edu/news/news-details.php?item=1603

Long after competiton: http://www.statler.wvu.edu/news/news-

details.php?item $=1980$

Journalism college articles:

http://mountaineernewsservice.com/wvu-to-compete-in-global-contest-to-build-solarpowered-house/

Office of Sustainability articles:

http://wecan.wvu.edu/sustainability/community and civic engagement/ wvu solar house 
For Earth Week:

http://wecan.wvu.edu/getinvolved/earthweek2013

WVU campus wide web press release:

http://wvutoday.wvu.edu/n/2013/01/04/wvu-solar-decathlon-team-ready-to-build-solarpowered-log-home

Ground Breaking Ceremony press release:

http://wvutoday.wvu.edu/n/2013/04/18/wvu-solar-decathlon-team-breaks-ground-onsolar-powered-log-home

Part of the campus strategic plan:

http://strategicplan.wvu.edu/the journey/news/solar-decathlon-2013

Campus intranet post:

http://intranet.wvu.edu/home/2012/7/31/modern-meets-rustic-in-wvu-solar-decathlonteam-s-design-for-energy-efficient-home http://intranet.wvu.edu/home/2012/1/27/they-re-in--wvu-students-selected-to-participatein-department-of-energy-s-solar-decathlon

WVU Higher Ed.--Division of Science and Research:

http://www.wvresearch.org/archives/5919 Long after competition:

http://www.wvresearch.org/archives/9697 
APPENDIX F

LEED v4 B. D. \& C. Scorecard

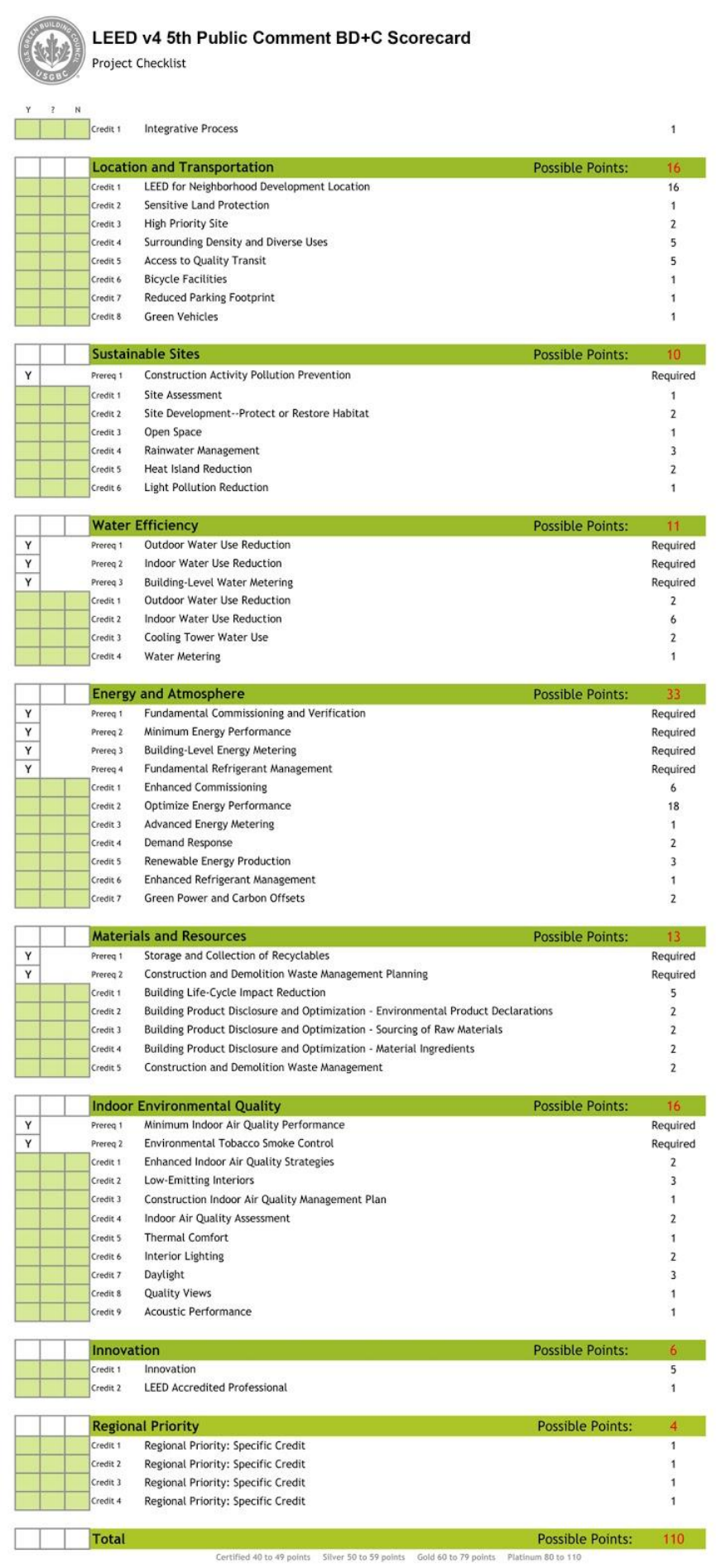

LEED v4 Building Design \& Construction scorecard 


\section{APPENDIX G \\ Questionnaire Results}

Note 1: Respondent Validation \& Approval included only data from "Milestones" Section

Note 2: Text next to respondent codes throughout this document is transcribed verbatim from surveys, with spelling corrections as needed.

Note 3: At Question 1, each respondent identifies the position s/he occupied on the WVU Solar Decathlon 2013 team. The researcher coded each position, as shown below, and carried the codes forward in alphabetical order for each subsequent questions.

\section{Questionnaire Results}

Note: Respondent Validation \& Approval included only data from "Milestones" Section

\section{Results: Q1. What was the title of your position during the competition?}

\begin{tabular}{|c|l|}
\hline DLC & Design Lead Coordinator \\
\hline EEL & Electrical Engineering Lead \\
\hline PRC & Public Relations Contact \\
\hline LAL & Landscape Architecture Lead \\
\hline
\end{tabular}

Results: Q2. What was (were) the overall successful aspect(s) of the project?

\begin{tabular}{|c|l|}
\hline DLC & Completing construction in Cali, learning new things \\
\hline EEL & $\begin{array}{l}\text { The level it got to, the outreach, the sponsorship, the teaching it provided, the networking, providing } \\
\text { new ways to think. }\end{array}$ \\
\hline PRC & $\begin{array}{l}\text { The overall successful part was building the house on the Competition site. In the end, we worked } \\
\text { together as a team to finish the job. }\end{array}$ \\
\hline LAL & $\begin{array}{l}\text { The most successful aspect of the project was the amount of teamwork and perseverance shown } \\
\text { throughout the design, construction, and competition phases. }\end{array}$ \\
\hline Results: Q3. What was (were) the overall unsuccessful aspect(s) of the project? \\
\hline DLC & Cockiness getting in the way of better choices, speed over quality \\
\hline EEL & Leadership, faculty involvement and guidance, always one step behind, time management. \\
\hline PRC & $\begin{array}{l}\text { The biggest setbacks we had were communication issues and not enough people to get the } \\
\text { deliverables done on time. }\end{array}$ \\
\hline
\end{tabular}




\begin{tabular}{|c|c|}
\hline LAL & $\begin{array}{l}\text { The communication between teams and individual team members was something that struggled all } \\
\text { the way until the final deconstruction day. }\end{array}$ \\
\hline \multicolumn{2}{|c|}{$\begin{array}{l}\text { Milestone 1: 09/23/12 - The team lead sent out rules and building codes documentation for the SD } \\
\text { competition and asks all leads to read them all over. }\end{array}$} \\
\hline DLC & $\begin{array}{l}\text { I was not yet a lead (January 2013) but only a member of the interior design team. Later on I printed } \\
\text { off all of the documentation and kept it in a binder for review. }\end{array}$ \\
\hline EEL & $\begin{array}{l}\text { I don't really remember, but I think there were times when leads sent out rules for everyone. I think } \\
\text { the lack of having someone that was specifically dedicated to them was a large problem. }\end{array}$ \\
\hline PRC & $\mathrm{N} / \mathrm{A}$ \\
\hline LAL & NA \\
\hline \multicolumn{2}{|c|}{ Milestone 2: 09/24/12 - SD leads gave a presentation to the Energy Club to recruit. } \\
\hline DLC & $\mathrm{N} / \mathrm{A}$ \\
\hline EEL & Sounds like they're looking in the right area of interest. \\
\hline PRC & $\begin{array}{l}\text { N/A-- But my sister was in the energy club at the time the presentation happened. I found out later } \\
\text { that she, as Energy Club president, was wanting the club to get involved in the project however no } \\
\text { one got back to her about it. }\end{array}$ \\
\hline LAL & NA \\
\hline \multicolumn{2}{|c|}{$\begin{array}{l}\text { Milestone } 3: 09 / 30 / 12 \text { - After emphasizing the importance of being sustainable whenever possible, leads } \\
\text { began looking for materials including: reclaimed timber, FSC lumber, recycled and composite products, and } \\
\text { energy efficient appliances. }\end{array}$} \\
\hline DLC & I spend a lot of time trying to find items that were truly sustainable for the house. \\
\hline EEL & $\begin{array}{l}\text { I think everyone was really enthralled by the idea of being "green" and wanted to run with it since it is } \\
\text { such a buzzword and looks good to the public. }\end{array}$ \\
\hline EM & $\mathrm{N} / \mathrm{A}$ \\
\hline LAL & $\begin{array}{l}\text { The search criteria for sustainable products led our team to finding the right products for a project } \\
\text { such as the SD. }\end{array}$ \\
\hline \multicolumn{2}{|c|}{$\begin{array}{l}\text { Milestone 4: 10/06/12 - I download the Autodesk architecture program Revit, and began familiarizing myself } \\
\text { with it. }\end{array}$} \\
\hline DLC & $\begin{array}{l}\text { I was not yet a lead (January 2013) but only a member of the interior design team. Later on I printed } \\
\text { off all of the documentation and kept it in a binder for review. }\end{array}$ \\
\hline EEL & I did download REVIT and did not familiarize myself with that program. I hate REVIT. \\
\hline PRC & $\begin{array}{l}\text { I also downloaded Revit but not until February of } 2013 \text {. Many of the students began working on it at } \\
\text { the same time I did from what I know. This was definitely something that was relevant to the project, } \\
\text { however it should have been addressed to the team much earlier. We were trying to work on the } \\
\text { deliverable at that same time as we were learning Revit, and that only caused us to be rushed and } \\
\text { confused. Also, the NCS (national cad standard) templates that should have been used from the } \\
\text { start were not familiarized with early on, thus putting us in trouble with the DOE. }\end{array}$ \\
\hline LAL & I was able to pick up on the movement of Revit due to my experience with AutoCad, another \\
\hline
\end{tabular}


Autodesk product.

Milestone 5: 10/18/12 - We began processes for the transition of leads, this happened every semester and sometimes more often.

\begin{tabular}{|c|l|}
\hline DLC & I applied to become Lead for the design team since my lead was about to study abroad. \\
\hline EEL & $\begin{array}{l}\text { Our transitions were not transitions but a violent metamorphoses and no clear way of passing on } \\
\text { knowledge. }\end{array}$ \\
\hline PRC & $\begin{array}{l}\text { As the leads changed, it wasn't a big problem for me if it was addressed to the team. For example } \\
\text { when a student lead graduated, and the entire team knew who would be taking their place. The } \\
\text { dynamic of the individual teams changed but it wasn't too bad to handle. }\end{array}$ \\
\hline LAL & $\begin{array}{l}\text { This is when I became regularly active in the project and actually achieved the Lead position. This is } \\
\text { when I discovered the scale of the Solar Decathlon Project. }\end{array}$
\end{tabular}

Milestone 6:11/10/12 - We began work on our revisions on the deliverables: BIM, Project Manual, and Revit Model. Consistently, we waited too long on starting our deliverables, we should have started these weeks beforehand.

\begin{tabular}{|c|l|}
\hline DLC & $\begin{array}{l}\text { I feel like the ID team never really revised deliverables. Meetings were sparse and sloppy and no } \\
\text { one even knew the layout of the home. }\end{array}$ \\
\hline EEL & $\begin{array}{l}\text { Yes, without a proper understanding of what exactly needs to be done. Our having a large pool of } \\
\text { ambiguity. This got better as time went on and a thousand revisions later. }\end{array}$ \\
\hline PRC & N/A \\
\hline LAL & $\begin{array}{l}\text { The organization of our deliverables was structured, but still could have used some perfection. Not } \\
\text { until the final deliverables, was there a person who checked every page before it. went to the DOE. }\end{array}$ \\
\hline
\end{tabular}

Milestone 7: 12/02/12 - I spoke with Dean Dan Robison of the Davis College about recruitment opportunities and Davis college involvement.

\begin{tabular}{|l|l|}
\hline DLC & N/A \\
\hline EEL & NA \\
\hline PRC & $\begin{array}{l}\text { I never spoke to the Dean of engineering but I did speak with the associate dean of engineering in } \\
\text { the spring semester of } 2013 \text { about the continuation of the solar decathlon project (the 2015 house). } \\
\text { He was very intrigued by the ideas we had so far and was very welcoming to us introducing the idea } \\
\text { of continuing with the project for the next competition. He provided feedback in terms of working with } \\
\text { the University of Rome tor Vergata again. }\end{array}$ \\
\hline LAL & NA \\
\hline $\begin{array}{l}\text { Milestone } \mathbf{8 : ~ 1 2 / 0 1 / 1 2 ~ - ~ A f t e r ~ s e v e r a l ~ a t t e m p t s ~ t o ~ s e c u r e ~ t r a i n i n g ~ f o r ~ p r o f e s s i o n a l ~ p r e s e n t a t i o n ~ s k i l l s , ~ t h e ~ P M ~} \\
\text { group tells me that they will manage this task, hoping that they will have better success with their available } \\
\text { influence. }\end{array}$ & N/A \\
\hline DLC & NA \\
\hline EEL & N/A \\
\hline PRC & NA \\
\hline LAL &
\end{tabular}


Milestone 9: 12/11/12 - We had our first fundraiser which proved not to help much.

\begin{tabular}{|c|l|}
\hline DLC & N/A \\
\hline EEL & $\begin{array}{l}\text { I don't really remember the first fundraiser, but most of our fundraisers never really provided a } \\
\text { substantial amount of help. }\end{array}$ \\
\hline PRC & N/A \\
\hline LAL & NA \\
\hline
\end{tabular}

Milestone 10: 12/15/12 - Several leads still have not read over the rules and building codes documentation, so I emphasize the importance that they all read them over.

\begin{tabular}{|c|l|}
\hline DLC & N/A \\
\hline EEL & It is above anything that the leads read and reread the rules and building codes. \\
\hline PRC & N/A \\
\hline LAL & I was one of the students who failed to read the rules, but soon after completed them. \\
\hline
\end{tabular}

Milestone 11: 01/01/13 - After several unsuccessful attempts to get timesheets from leads, the PI tells me to devote my time to other responsibilities.

\begin{tabular}{|l|l|}
\hline DLC & N/A \\
\hline EEL & NA \\
\hline PRC & N/A \\
\hline LAL & NA \\
\hline
\end{tabular}

Milestone 12: 01/16/13 - We struggled to find a time that we could all meet for leads meetings.

\begin{tabular}{|c|l|}
\hline DLC & I entered my schedule into Google Calendars so my availability was known. \\
\hline EEL & We dedicated time each week to have leads meeting. \\
\hline PRC & N/A \\
\hline LAL & $\begin{array}{l}\text { Working out schedules was a difficult for our team, especially a team of students. It seemed that the } \\
\text { best way to have meetings was to have them on weekends and then the establishment of a } \\
\text { scheduled class. }\end{array}$ \\
\hline
\end{tabular}

Milestone 13: 02/02/13 - I pushed for metal roofing for it is more sustainable than shingles, it was discussed and decided that I was right. We also discussed using a solar water heater as a preheater for the house. I also push for an in-line water heater, but because a sponsor was supplying that hardware and they didn't have them.

\begin{tabular}{|c|l|}
\hline DLC & $\begin{array}{l}\text { LEED was discussed and a girl was put in charge of seeing if it was possible but she quit. Also, now, } \\
\text { is it even possible since one of the requirements is the house be on a permanent location and ours } \\
\text { was moved? }\end{array}$ \\
\hline EEL & There was always talk of LEED but I never really cared to know more about it. \\
\hline PRC & $\begin{array}{l}\text { I know that a standing seam roof was very helpful when installing the solar panels. It made mounting } \\
\text { the (solar panel) railings a lot easier. }\end{array}$ \\
\hline
\end{tabular}


LAL

Both of these materials proved to be the right choice. The metal roof aided in the ease of storm water catchment. The solar hot water heater was a great addition, and would not have had a place to be put unless the FANTASTIC Landscape Architecture lead pushed for the use of the Carport. Both the roof and solar hot water heater definitely helped us gain support from the DOE.

Milestone 14: 02/03/13 - I stressed that we needed to start reaching out to our various university media resources to help with university support and recruitment. I assigned a member to lead this task and gave periodic inquiries on progress, but the member did not follow through.

\begin{tabular}{|c|l|}
\hline DLC & N/A \\
\hline EEL & I didn't really care about the university media resources but they did a good job. \\
\hline PRC & $\begin{array}{l}\text { I was very adamant about this as well. I felt that we needed more outreach to represent the team in } \\
\text { our community. I also decided that the team needed an Instagram page so I made one for us! }\end{array}$ \\
\hline LAL & NA \\
\hline
\end{tabular}

Milestone 15: 02/04/13 - I remind the LA about the help that is available for the vegetation because it's indicated to me that there was no communication. This continued to be a problem, this is partly because we continue to have issues with the Communications group. They still haven't finished the donor packet and don't communicate to donors as supposed to. We continue to ask and to stress to their advisers that work is not getting done, all to no avail.

\begin{tabular}{|c|l|}
\hline DLC & A lot of things were kind of sloppy. \\
\hline EEL & $\begin{array}{l}\text { This is a mostly true. The coms group can't spend time with donors because they generally would } \\
\text { have no idea what was being talked about. The problem: our interaction were 1:1 and so a lot of } \\
\text { information was spread thin. }\end{array}$ \\
\hline PRC & N/A \\
\hline LAL & $\begin{array}{l}\text { There may have been some difficulties with the incorporation of vegetation in the early stages. The } \\
\text { end result, however, managed to award us with the house that best blended technology and nature } \\
\text { which I highly dedicate to the exterior and interior use of plantings. }\end{array}$
\end{tabular}

Milestone 16: 02/04/13 - We had issues with the members not showing up to their 10 hour safety training: coming in late or not showing up for one of the three training sessions.

\begin{tabular}{|c|c|}
\hline DLC & $\begin{array}{l}\text { The Health and Safety members were rarely seen and didn't seem to do their tasks, leaving them for } \\
\text { others to complete. }\end{array}$ \\
\hline EEL & Yea, they weren't really there and I don't think they cared. \\
\hline PRC & $\mathrm{N} / \mathrm{A}$ \\
\hline LAL & $\begin{array}{l}\text { The HS team was surely one of our weakest links that in the end managed to take away some useful } \\
\text { resources at important times to finish the uncompleted plan. }\end{array}$ \\
\hline \multicolumn{2}{|c|}{ Milestone 17: 02/04/13 - We also discussed the need for the BIM to be National CAD Standards compliant. } \\
\hline DLC & A few people were assigned to do this. Eventually I learned a little bit about it and was able to help. \\
\hline EEL & Sure. Having a group that solely focused on this would have been awesome. \\
\hline PRC & $\begin{array}{l}\text { If there was a group, I was definitely on it in terms of NCS compliant. I've explained my situation in } \\
\text { this. The only thing that could have helped our consistency issue would have been to work in NCS } \\
\text { templates earlier. }\end{array}$ \\
\hline LAL & When we began to use the standards, our BIM began to carry a consistent look, one that we did not \\
\hline
\end{tabular}


have for any other deliverable prior to that use.

Milestone 18: 02/06/13 - We continued to have regular meetings, this is another thing we did well.

\begin{tabular}{|c|l|}
\hline DLC & Leads meetings were held at regular times and most leads attended all. \\
\hline EEL & We did pretty well at making sure we were meeting, though I don't know how productive they were. \\
\hline PRC & $\begin{array}{l}\text { We did meet on a regular basis. Even though there was communication problems, this helped the } \\
\text { entire team stay on the same page. The DOE is not against us and they really want to see us } \\
\text { succeed in the competition. This became clearer when we were in CA working directly with them. }\end{array}$ \\
\hline LAL & The team meetings were very useful.
\end{tabular}

Milestone 19: 02/14/13 - We submitted our second set of major deliverables-

Construction Documentation: BIM, Revit model, Project Manual, HSP, and revised Cost Estimate.

\begin{tabular}{|c|c|}
\hline DLC & $\begin{array}{l}\text { Alongside the new ID lead, we found and submitted all design products, specs, and pricing for the } \\
\text { interior portion of the deliverable. They were also inserted into Revit. }\end{array}$ \\
\hline EEL & $\begin{array}{l}\text { The largest feelings of accomplishment that were quickly fleeting in sight of what still needed to be } \\
\text { done. }\end{array}$ \\
\hline PRC & $\begin{array}{l}\text { I was just getting familiar with the project when this deliverable was submitted. It was obvious we } \\
\text { struggled with getting the material ready and submitted on time. Especially since it was not approved } \\
\text { and we had to continually resubmit. During one of the resubmission periods we were on spring } \\
\text { break, and only a few of us were in town. It fell heavily on us few to get the job done efficiently, and I } \\
\text { was given a lot of responsibility to adjust the drawings to national cad standards. While working } \\
\text { alone I felt I was not working fast enough and it could have been better handled with more than one } \\
\text { person. However in the long run we all were able to get the deliverable together and accepted by the } \\
\text { DOE. }\end{array}$ \\
\hline LAL & $\begin{array}{l}\text { This was the night of my birthday that we worked on Revit for } 16 \text { hours straight. We managed to turn } \\
\text { in the deliverable on time. HOWEVER, we completed about double the work required because we } \\
\text { needed to keep linking to the server which caused other students to lose their work. }\end{array}$ \\
\hline \multicolumn{2}{|c|}{$\begin{array}{l}\text { Milestone 20: } 04 / 09 / 13 \text { - After calculating all of the lumber that would be needed to build the house, the } \\
\text { company that we had agreements to donate lumber for us backed out on the eleventh hour. So we make a } \\
\text { mad dash to contact every local company with hopes that they will donate or give us reduced costs on } \\
\text { lumber. }\end{array}$} \\
\hline DLC & I contacted Dr Haddox and Dr DeVallance for suggestions. \\
\hline EEL & We really had no other choice. It sucked. \\
\hline PRC & This was a financial struggle for the team, and will be considered much early on in the next project. \\
\hline LAL & $\begin{array}{l}\text { In the professional world, a thing I learned about a lot through this project, the company that did this } \\
\text { to us would typically receive a poor reputation. I would recommend to find a new company aside } \\
\text { from them with future SD involvement. }\end{array}$ \\
\hline \multicolumn{2}{|c|}{$\begin{array}{l}\text { Milestone } 21: 04 / 10 / 13 \text { - I continually was the one to go to for information in all aspects of the house like } \\
\text { measurements, area, volume, square footage, linear footage, materials, layers, location, placement, angles, } \\
\text { etc. }\end{array}$} \\
\hline DLC & I used the existing measurements for my portion of the project and helped with them when needed. \\
\hline EEL & Everyone was always doing this. \\
\hline PRC & N/A- No one came to me for that, I went to others (DLC or PM). \\
\hline
\end{tabular}




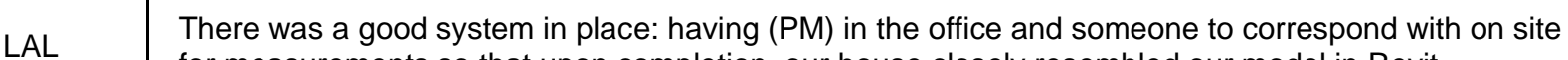
for measurements so that upon completion, our house closely resembled our model in Revit.

Milestone 22: 04/17/13 - I continued to have issues with getting members to attend OSHA training, this was understandably conflicting with and aggravating for both SHE and myself.

\begin{tabular}{|c|l|}
\hline DLC & I attended all OSHA trainings I needed. \\
\hline EEL & Yea, also trying to get their work done. \\
\hline PRC & $\begin{array}{l}\text { OSHA training was the most necessary safety precaution to take when it came to construction. } \\
\text { Knowing we will do the project again, we have already begun talks about getting student OSHA } \\
\text { certified. }\end{array}$ \\
\hline LAL & $\begin{array}{l}\text { I was able to make OSHA the first time offered. I know from talking to people, that transportation was } \\
\text { sometimes an issue, but there is a simple solution: CARPULL! }\end{array}$ \\
\hline
\end{tabular}

Milestone 23: 04/30/13 - We continued work on the master material list, adding whether we got the item or not.

\begin{tabular}{|c|l|}
\hline DLC & I added all of the design materials, quantity, cost, company, etc. to the materials list. \\
\hline EEL & The master material list was a hot mess and was maintained horribly. \\
\hline PRC & N/A \\
\hline LAL & $\begin{array}{l}\text { The categorical break up of materials helped us make sure we had an accurate checklist. This was } \\
\text { usually done by the leads and it proved effective. }\end{array}$ \\
\hline
\end{tabular}

Milestone 24: 08/02/13 - After working on the HSP tediously, and after learning how to write it, I was able to complete the plan, successfully, to the DOE's requirements.

\begin{tabular}{|c|l|}
\hline DLC & N/A \\
\hline EEL & NA \\
\hline PRC & $\begin{array}{l}\text { N/A- But it should have been stressed more to the team that everyone should read the HSP and be } \\
\text { familiar with it. }\end{array}$ \\
\hline LAL & $\begin{array}{l}\text { The Health and safety plan, again, was one of the most tested areas for our team. (PM) was able to } \\
\text { learn the system, understand it, and then write a plan that was able to pass the standard for the } \\
\text { DOE. }\end{array}$ \\
\hline
\end{tabular}

Milestone 25: 07/19/13 - With the generous and most appreciated help from our new structural engineers and after assisting Lawson-Burke with drawings from the Revit Model and creating sheets for the BIM, we successfully submitted Stamped Structural Calculations and Drawings to the DOE.

\begin{tabular}{|c|l|}
\hline DLC & NA \\
\hline EEL & Stamped twice! After we panicked, of course. \\
\hline PRC & $\begin{array}{l}\text { I was very worried we were not going to be able to continue with the project since we were } \\
\text { desperate for a structural engineer. }\end{array}$ \\
\hline LAL & NA You dealt with them the most (PM). \\
\hline
\end{tabular}

Milestone 26: 08/22/13 - After getting a message from the DOE warning us that if we do not get our revisions completed and approved to our BIM we would be disqualified, and after a week of near around the clock, working on Revit by the researcher and an Electrical Engineering student also familiar with Revit, were able 


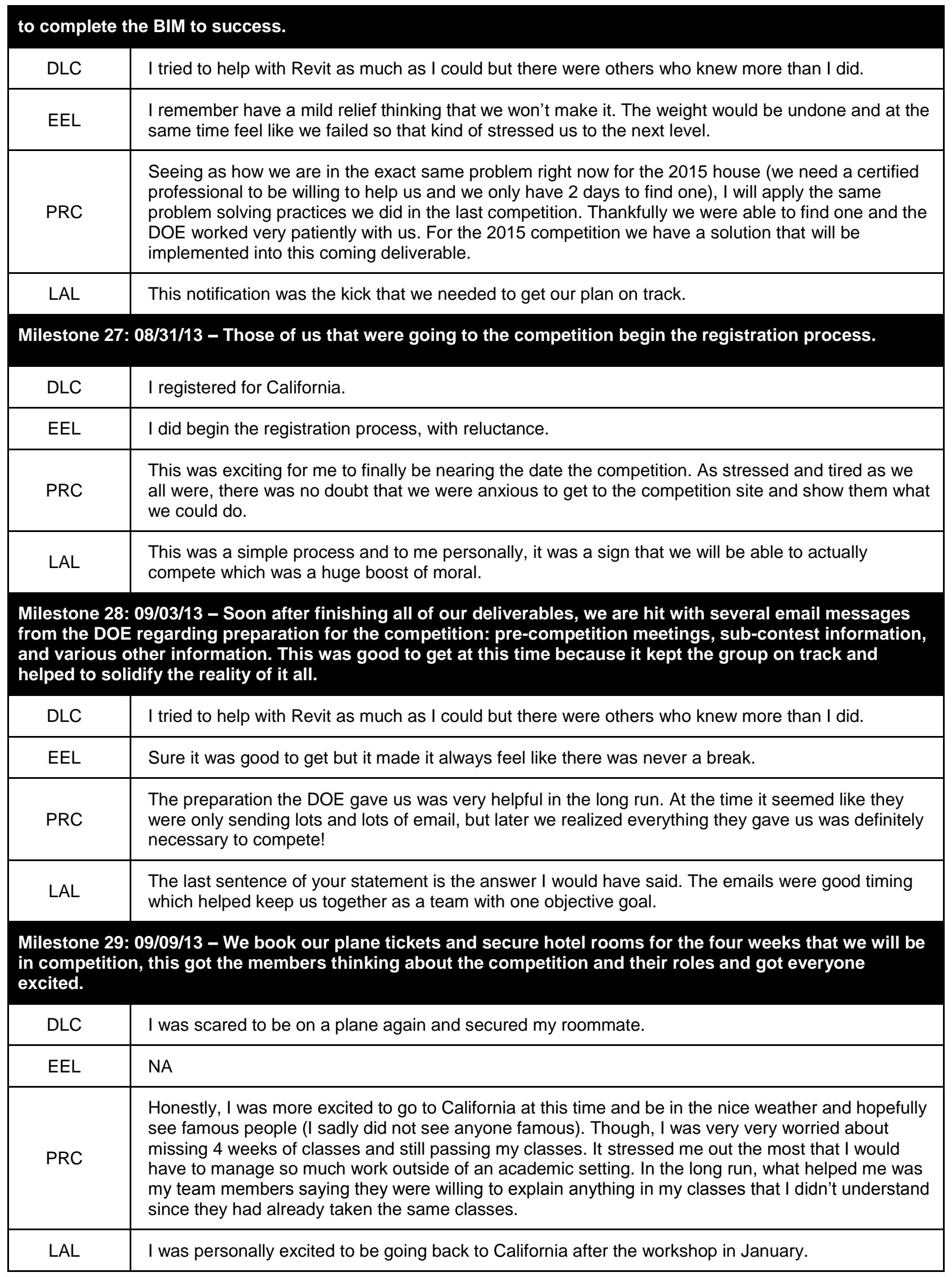


Milestone 30: 09/11/13 - We receive news that team Tidewater Virginia will be unable to compete, We feel bad, knowing what we had gone through but still able to compete, it must have been pretty bad for them.

\begin{tabular}{|c|l|}
\hline DLC & $\begin{array}{l}\text { I thought it unfortunate that a team came so far only to miss competition but was secretly happy and } \\
\text { though "Well, even if we finish last we're not truly last." }\end{array}$ \\
\hline EEL & I remember the overall reaction was, "Woohoo, we won't be dead last." \\
\hline PRC & Hey we're not going to be in dead last. Less competition, more gain. \\
\hline LAL & $\begin{array}{l}\text { This was a sign that without one last final push, that WVU too could be dropping out. We felt terrible } \\
\text { for all of the people who dedicated all of their hard work for nothing. }\end{array}$ \\
\hline
\end{tabular}

Milestone 31: 09/17/13 - As we were preparing for the competition, we failed to pay close attention to the email that were sent from the DOE weeks before we left to CA; in them were good tips and templates that would have been helpful to absorb.

\begin{tabular}{|c|l|}
\hline DLC & N/A \\
\hline EEL & NA \\
\hline PRC & $\begin{array}{l}\text { These items would have been very helpful early on in the design process. But seeing as I am } \\
\text { working on the next house, I know the DOE tries to provide as much help as possible in the design } \\
\text { group. Also, I am able to provide our team with the materials and examples I have gotten from the } \\
2013 \text { competition. }\end{array}$ \\
\hline LAL & NA \\
\hline
\end{tabular}

Milestone 32: 10/15/13 -Began the disassembly of the house, we had 5 days to tear down the house and erase all traces that we were there (except the holes we drilled for anchoring). We did this exceptionally well, having no issues except for the fulcrum collapsing and breaking to pieces.

\begin{tabular}{|c|l|}
\hline DLC & $\begin{array}{l}\text { As soon as the last tour was done in the house we changed into construction gear and started } \\
\text { disassembly. }\end{array}$ \\
\hline EEL & NA \\
\hline PRC & $\begin{array}{l}\text { Easy part because we didn't have to remeasure anything or use drills as much since those were a } \\
\text { rare acquirement. }\end{array}$ \\
\hline LAL & $\begin{array}{l}\text { This was certainly and interesting process that resulted in the loss of a majority of our merchandise } \\
\text { and material. I was personally mortified to watch the fulcrum walls tumble on top of the stone work } \\
\text { that Stallone and I so diligently assembled. }\end{array}$ \\
\hline
\end{tabular}

Milestone 33: 10/20/13 - We flew back to Morgantown with everyone accounted for.

\begin{tabular}{|c|l|}
\hline DLC & N/A \\
\hline EEL & I'm glad that we didn't have a missing persons problem because that would just look great. \\
\hline PRC & $\begin{array}{l}\text { It felt great to be back having competed and actually completed the house. We had a lot of setbacks } \\
\text { in the competition but we still succeeded in so many other ways. For me the point was to go out } \\
\text { there and represent WVU, and we did. So little people will know what we went through in the } 2013 \\
\text { competition, but the bond we formed as a team will never be forgotten. It's definitely the most I have } \\
\text { taken from the project. }\end{array}$ \\
\hline LAL & $\begin{array}{l}\text { This was great that no one died. I was extremely excited that everyone was in good spirit and that } \\
\text { there was a football game the next day. }\end{array}$ \\
\hline Results: Q37. Are there any significant events we were involved in that was (were) not included in the
\end{tabular}




\begin{tabular}{|c|c|}
\hline DLC & The actual construction phase both here and in California. \\
\hline EEL & Probably but I can't really think of any at the moment. \\
\hline PRC & I think you hit most of them. \\
\hline LAL & $\begin{array}{l}\text { The overall experience itself. But you and I have talked so many times on the subject for you to not } \\
\text { know that this was the best experience of my life. }\end{array}$ \\
\hline DLC & $\begin{array}{l}\text { I would contact prospective donors for design materials myself instead of getting them thrown on the } \\
\text { back burner. Communication needed changed a lot. Storage space and/or an indoor building } \\
\text { location. }\end{array}$ \\
\hline EEL & The stress that was constant and ultimately drove us from wanting to even work with one another. \\
\hline PRC & $\begin{array}{l}\text { There are a few things that I would change. In general just how to handle certain things, when to } \\
\text { start preparing the team for a specific task, how to enforce work, etc. It's a learning process for } \\
\text { everybody through the } 2 \text { years of the project. }\end{array}$ \\
\hline LAL & $\begin{array}{l}\text { Communication. In addition to that there, at times, should have been votes of confidence to remove } \\
\text { some of the leads. }\end{array}$ \\
\hline
\end{tabular}

